\title{
An Accounting Liability Heuristic
}

Timothy B. Lewis, J.D., MAcc, Southern Utah University, USA

Jeffrey N. Barnes, DBA, MAcc, CPA, Southern Utah University, USA

\begin{abstract}
This article traces the thought processes involved in understanding and managing accountants' legal liability which is sometimes broadly called "professional malpractice." The cumulative nature of potential liability is demonstrated. The various legal theories of liability are discussed along with the most prominent potential affirmative defenses against liability. Unique to this paper is the decision heuristic providing a framework for assessing potential accountants' legal liability. This discussion is useful for both student and practitioner.
\end{abstract}

Keywords: Accounting Fraud; Accountants' Legal Liability; Accounting Malpractice; Accounting Negligence; Credit Alliance; Bily; Private Securities Litigation Reform Act Of 1995; Privity Of Contract; RICO; Restatement Of Torts; Rosenblum; Sarbanes Oxley; Securities Act Of 1933; '33 Act; Securities Exchange Act Of 1934; '34 Act; Ultramares

\section{INTRODUCTION}

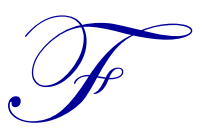
flowchart format to simplify the analysis and management of an accountant's legal risks. This should be helpful to both accounting students and practitioners.

As a matter of trial management by the courts, plaintiffs are effectively forced to bring every possible theory of liability imaginable against the defendant because the courts want to handle all legal issues between the litigants in a single court case. They won't allow the plaintiff to split one legal cause of action into multiple lawsuits based upon different theories of liability derived from the same set of facts. In other words, if the first case didn't result in an acceptable damage award in favor of the plaintiff based upon one theory of liability, it cannot file another lawsuit on a different theory, to see if things turn out better the second, third, etc., time around. The plaintiff will be "estopped" from filing multiple lawsuits based upon the same facts.

Because of this rule of court administration, plaintiffs tend to get very long winded in their complaints in coming up with every possible theory of liability they can think to raise against the defendant. They don't expect to win under every theory but hope to win enough of their legal theories to get acceptable damage awards against their defendants.

As a general rule and relatively speaking, when one reads a professional malpractice complaint, the first legal theories of liability mentioned seem to be quite understandable and straight forward. But as one moves down the list of legal theories for relief, they become more obscure in nature. This is because of the aforementioned rule of court administration.

Not wanting to forget any potential legal theory and then later be denied the ability to raise it at trial, sometimes the list of legal theories for relief stated in the original complaint include things that seem almost unintelligible. The intent of the plaintiff's attorney is to leave the door open to raise some other legal theory for liability, if and when, it later coalesces more clearly in his mind. An old phrase to describe this process is: "He threw everything at him including the kitchen sink." - the "kitchen sink" would be that obscure, grasping-for-straws final attempt to express a viable legal theory of liability against the defendant. From a practical standpoint, that 
means that when an accountant is sued civilly, he can expect to be forced to respond to a multiplicity of legal theories that will be alleged against him by the plaintiff.

The purpose of this article and flowchart is to give the reader a very basic understanding of probable legal issues in a broad sense. It is only designed to help the reader see the "big picture" and is not designed to address every possible legal issue that might arise in the course of trial-just the ones that have the highest prospects for danger to an accountant.

There are three main potential theories of liability against an accountant, namely, (1) common law contractual liability under state law, (2) common law tort liability under state law, and (3) statutory law at both the federal and state levels.

In this context, "common law" refers to the various legal rules that originated in various judicial rulings and are generally followed by the courts under the judicial doctrine known as stare decisis which means "to abide by, or adhere to, decided cases." That is in contrast to "statutory law" which refers to the various bills that pass through the state legislatures or the federal Congress, and are signed into law by the Governors of the states on the one hand, or the President of the United States on the other. Sometimes this is called "code law" since the various statutes are compiled in the various state codes or the United States Code (U.S.C.)

\section{A. The Common Law of Contracts}

The flowchart begins with a basic analysis of the Common Law of Contracts. If one of the legal theories for relief alleged by the plaintiff is "breach of contract," we must consider two broad aspects of it, namely: is the plaintiff (1) the client of the accountant or (2) a $3^{\text {rd }}$ party user of the accountant's work product?

Whichever parties agree to a particular contract, are said to be in "privity of contract." So the accountant and his client would be described as such regarding their "engagement letter." Engagement letters are really contracts. We would prefer they be called "engagement contracts" instead of "engagement letters" in order for the accountants and their clients to really appreciate the seriousness of what they are doing. In this article we will use the term "engagement contract."

In the legal sense, when we speak of a particular engagement contract, while the accountant and his client are said to have a relationship of "privity," everybody else in the world is referred to as a " 3 rd party" relative to that contract.

Most of the time the defendant in a breach of contract action relative to a professional engagement contract, is the accountant or accounting firm (hereafter referred to as accountant or auditor). It could be the client but that would probably only be the case where an accountant did his work properly and was suing his client to collect his bill for the services rendered. Accountants would be well advised to be very cautious about suing their clients for unpaid bills, since it might prompt counterclaims by their clients of professional misconduct by the accountant prompting liability the other direction. This is an application of the old adage: "Let sleeping dogs lie!"

\section{$3^{\text {rd }}$ Parties' Rights in Other People's Contracts}

The general rule in contract law is that $3^{\text {rd }}$ parties have no rights or obligations regarding other people's contracts. One exception to this general rule is " $3{ }^{\text {rd }}$ party beneficiary contracts." ${ }^{2}$ It is possible for a 3 rd party user of the accountant's work product, to claim that the professional engagement contract between the accountant and his client was a " 3 rd party beneficiary contract" intended to benefit that $3{ }^{\text {rd }}$ party thus, entitling him to sue the accountant for breach of contract.

\footnotetext{
${ }^{1}$ Black's Law Dictionary, Revised $4^{\text {th }}$ edition, p. 1577.

${ }^{2}$ The old N.Y. case of Lawrence v. Fox (20 N.Y. 268 (1859)) is generally credited with the creation of this theory and is recognized in almost all states. See Contracts $2^{\text {nd }} E d$, by John D. Calamari and Joseph M. Perillo (West Publishing Company, Hornbook Series (1977) p.606).
} 
Generally speaking, for a $3^{\text {rd }}$ party to win such an argument, he must convince the court that (1) he was an "intended" (as opposed to a merely "incidental") beneficiary, (2) "vesting" has taken place, and (3) the defendant breached the contract causing provable damages to the plaintiff (i.e. the $3^{\text {rd }}$ party beneficiary.) ${ }^{3}$

Regarding "intended" versus "incidental" beneficiaries, the courts generally try to discern whether or not the one who named that $3^{\text {rd }}$ party as a beneficiary really wanted him to have personally-enforceable rights in the contract. The most common types of intended beneficiaries are "donee beneficiaries" and "creditor beneficiaries."

In the case of a "donee beneficiary," the one naming the $3^{\text {rd }}$ party as a beneficiary under the contract intended to make a gift to that $3^{\text {rd }}$ party. In the case of a "creditor beneficiary," the one naming the $3^{\text {rd }}$ party as a beneficiary under the contract, owed him something and was trying to satisfy that legal obligation (at least partially) through this contract with another party. ${ }^{5}$

Most likely, a $3^{\text {rd }}$ party attempting to sue an accountant for breach of contract regarding his professional engagement contract with his client, would claim to fall within the "creditor beneficiary" category. That is because in the accounting malpractice context, the accountant's client would be the one who purportedly named the $3^{\text {rd }}$ party as an intended beneficiary of the accountant's audit work. In several malpractice law suits the $3^{\text {rd }}$ party who sued the auditor was a creditor of the audit client and claimed it was hurt by relying upon the auditor's faulty audit work and/or audit report. ${ }^{6}$

Often times, people are able to glean only some tangential benefits from other people's contracts- these people are called merely "incidental beneficiaries" and generally have no recognized legal claims regarding other people's contracts. ${ }^{7}$

To use an analogy, when you make your dinner for your family and your dog gets the resulting scraps, all of your family members were the "intended beneficiaries" of you culinary efforts, but your dog was just an "incidental beneficiary" of those efforts. Their complaints will likely be seriously considered, but the dog would have no legitimate claim or "legal standing" to complain about the meal.

Even if the $3^{\text {rd }}$ party could successfully claim that he was an "intended beneficiary," his legal claim will fail unless "vesting" has occurred. ${ }^{8}$ Generally, vesting in this context occurs when the $3^{\text {rd }}$ party (1) finds out about the contract and (2) somehow objectively manifests assent to it. Such manifestations of assent might include expressing gratitude for what the contracting parties did in his behalf; changing position in reliance on the expectation of receiving the benefit that will accrue to him under that contract; suing over the contract; etc.

A $3^{\text {rd }}$ party's malpractice claim against an accountant for mis-performing his professional obligations to his client, is very confusing since his claim for breach of contract under a $3^{\text {rd }}$ party beneficiary contract seems so similar to a his potential tort claim of negligence against that accountant. In both contexts, the courts seem to struggle in determining whether or not the accountant owed any legal obligations to that $3^{\text {rd }}$ party which would effectively give him the legal standing to sue the accountant for some type of professional malpractice. ${ }^{9}$

\footnotetext{
${ }_{3}^{3}$ Contracts $2^{\text {nd }}$ Ed, by John D. Calamari and Joseph M. Perillo (West Publishing Company, Hornbook Series (1977) pp.606-07, 625-28).

${ }^{4}$ Id. pp.606-607.

${ }^{5}$ For an example of a potential creditor beneficiary arrangement, consider the situation where the audit client has borrowed money from a creditor which has imposed various debt covenants to be met at the risk of calling the loan due if the debtor lapses into non-compliance. If the creditor required an audit be done to determine continuing compliance, it could argue that it was a $3^{\text {rd }}$ party creditor-beneficiary of the audit engagement allowing it to sue the auditor for faulty attestation work concerning compliance with those debt covenants.

${ }^{6}$ Ultramares Corp. v. Touche (174 N.E. 441 (N.Y. 1931.)); Rusch Factors v. Levin (284 F.Supp. 85 (R.I., 1968)); Citizens State Bank v. Timm Schmitt (335 N.W.2d 361 (WI, 1983)); Credit Alliance v. Arthur Andersen (483 N.E.2d 110 (N.Y., 1985)).

${ }^{7}$ Contracts $2^{\text {nd }}$ Ed, by John D. Calamari and Joseph M. Perillo (West Publishing Company, Hornbook Series (1977) pp.607-13.)

${ }^{8}$ Id. pp.625-28.

${ }^{9}$ While some might use the term "professional malpractice" very narrowly to describe just negligence, we use the term broadly to describe all the potential bases for liability discussed in our flowchart.
} 
To decide that matter in the tort context, the courts tend to ask the following question: "To whom did the accountant owe a "duty of care?" To decide that matter in the context of a $3^{\text {rd }}$ party beneficiary contract, the courts tend to ask the following question: "Was the $3^{\text {rd }}$ party plaintiff a type of intended beneficiary who was vested?"

In both contexts the courts struggle in their efforts to clearly determine when they should carve out exceptions to the general rule that $3^{\text {rd }}$ parties have no rights or obligations regarding other people's contracts. The courts tend to look at the matter from a tort perspective rather than a $3^{\text {rd }}$-party-beneficiary-contract perspective. This may be because the client seldom specifically tells its auditor to whom it (the client) intends to show the audited financial statements.

\section{The Client's Breach of Contract Claims Against Its Accountant}

When a client sues its accountant for "breach of contract," the first question becomes: "What were the terms of that contract?" Terms can be (1) expressly agreed upon in the engagement contract, or (2) implied by law.

In drafting the engagement contract, the accountant should be careful not to include ambiguous terms. An ambiguity is a word or phrase that has more than one possible reasonable meaning. If any ambiguities exist in the engagement contract, a common rule of legal interpretation is to interpret them against the interests of the one who drafted the written contract ${ }^{10}$, which in our case, would most likely be the accountant.

Another common rule of legal interpretation is what is called "the plain meaning rule." Under this rule, the express words used in the contract are given their plain meaning.

Both of the foregoing rules can be illustrated by a case called Fund of Funds v. Arthur Andersen. ${ }^{12}$ In that case the auditors promised to disclose to its client (Fund of Funds) any "irregularities" they discovered in the course of their audit work. The defendant auditors sought to have the court apply a narrow and technical meaning to that term but instead, the court applied a broad meaning to that term—one that favored the plaintiff client.

Not only did Arthur Andersen audit Fund of Funds but also audited some other companies that did business with Fund of Funds. During the course of its audits of everyone, Andersen consulted the books of all those entities in order to determine how various transactions between them should be reported in their respective financial statements. In doing that, Andersen discovered that these other companies were committing fraud against Fund of Funds. Andersen never disclosed those frauds to Fund of Funds and Fund of Funds later sued Andersen for "breach of contract" for not disclosing such "irregularities" as per the dictates of their express contract.

Even though Andersen argued that the term "irregularities" had a limited technical meaning and was not meant to cover such things as fraud, the court interpreted that term broadly and in favor of Fund of Funds. Thus it ruled that Andersen breached that express term of their engagement contract with Fund of Funds.

\section{$\underline{\text { Implied Contractual Terms }}$}

In addition to whatever express terms are agreed to between the accountant and his client, the law may imply other terms, which if not properly observed by the accountant, will form the basis of a "breach of contract" law suit against him by his client.

For example, the following contractual terms were implied by law against accountants: an implied duty to use reasonable care in the performance of its professional services ${ }^{13}$; an implied duty of confidentiality ${ }^{14}$; an implied duty to follow up on suspicions ${ }^{15}$; going beyond the normal scope of a compilation may imply that a review (or

\footnotetext{
${ }^{10}$ Contracts $2^{\text {nd }}$ Ed, by John D. Calamari and Joseph M. Perillo (West Publishing Company, Hornbook Series (1977) pp.119-21.)

${ }^{11}$ Id. pp.117-18.)

${ }^{12}$ Fund of Funds v. Arthur Andersen (545 F. Supp. 1314 (SDNY, 1982.))

${ }^{13}$ U.S. v Simon (425 F.2d 796 ( $2^{\text {nd }}$ Cir. 1969.))

${ }^{14}$ Wagenheim v. Alexander Grant (482 N.E.2d 955 (Ohio App. 1983.))

${ }^{15}$ Ultramares Corp. v. Touche (174 N.E. 441 (N.Y. 1931.))
} 
perhaps even an audit) was actually involved even though the express contract between the accountant and the client did not say so ${ }^{16}$, etc.

It should be noted that just following Generally Accepted Auditing Standards (GAAS) and Generally Accepted Accounting Principles (GAAP) may not be legally sufficient in meeting an auditor's duty of care owed to its client. In the Simon ${ }^{17}$ case, seven eminent accounting experts testified that requiring the footnote to the financial statements produced by the auditors to disclose a particular thing ${ }^{18}$ would have violated GAAP. Nevertheless, the court said the auditors were legally duty bound to disclose those things at the risk of facing criminal sanctions for not doing so. Surely, if following GAAP would not necessarily protect an auditor from criminal sanctions, it would not necessarily protect an auditor from a breach-of-contract claim regarding implied contractual obligations or from a tort claim for negligence.

Once the court determines the express and implied terms of the contract, it will determine whether or not any of those terms were violated. If the plaintiff can convince the court that any were violated, then the plaintiff client can recover damages to the extent it can prove its injuries. If none of those terms were violated, then the plaintiff will lose its "breach of contract" theory for relief and will have to try to prove its other theories for legal relief, a discussion of which follows.

\section{Punitive Damage Awards are Rare in Breach-of-Contract Cases}

It should be noted that punitive damage awards are very rare under the "breach of contract" theory. Punitive damages are designed to civilly punish egregious behavior and make an example out of the defendant to discourage him and others from committing similar atrocious behavior in the future. Normally, such damages are only awarded when intentional torts (like fraud) are involved. ${ }^{19}$ Mere claims of negligence are likewise usually insufficient to justify an award for punitive damages. ${ }^{20}$ Compensatory damages and consequential/special damages (sometimes both of these types of damages are lumped together and called "actual damages") are designed to make the injured party whole which is the normal purpose of civil remedies.

\section{B. Common Law Tort Theories of Liability}

There are three general areas of tort liability. In orders of culpability from least bad to worst, they are negligence, gross negligence, and fraud. From the accountant's perspective, if the court finds that he committed a tort, hopefully the court finds him to have been merely negligent instead of worse since otherwise he faces the prospects of (1) having to pay punitive damages in addition to the plaintiff's actual damages, (2) not having any coverage under his malpractice insurance policy because of possible exclusions in the policy, (3) losing his Certified Public Accountant (CPA) license (or submitting to other practice-restrictive sanctions), and (4) criminal prosecution. Negligence

One of the most important issues in a negligence law suit is whether or not the accountant owed any legal "duty of care" to the plaintiff. This is because liability only occurs when the defendant accountant breached such a duty of care. Unquestionably, he owes a duty of care to his client since they are "in privity of contract." But what about $3^{\text {rd }}$ parties?

\footnotetext{
${ }^{16} 1136$ Tenants v. Max Rothenberg and Co. (36 A.D.2d 804 (N.Y., 1971.))

${ }^{17}$ U.S. v Simon (425 F.2d $796\left(2^{\text {nd }}\right.$ Cir. 1969.))

${ }^{18}$ There, a man name Roth controlled two companies. The one company-the audit client--loaned millions of dollars to the other company which, in turn, loaned the money to Roth personally who lost it in failed stock market speculations. When Roth was unable to repay his personal debt to the one company, it could not repay its debt to the company being audited by the defendant-auditors. The audit client eventually became insolvent because of these bad loans. The question was whether or not the auditors who knew about these things were legally obligated to disclose this information in their audit opinion at that stage of GAAP development. All of the eight expert accounting witnesses who testified said that at the time of the audit, GAAP did not require the disclosure of the loans to Roth. Seven of those eight even went so far as to say such disclosures would actually violate GAAP. Nevertheless, the court said the auditors were legally bound to disclose that information in their audit opinion.

${ }^{19}$ See for example, NJ Revised Stat. Section 2a:15-5.12 (2014). This New Jersey statute requires the presence of "actual malice" or "wanton and willful" disregard of others who might foreseeably be harmed by the defendant's acts or omissions. It specifically says that mere negligence or even gross negligence are not enough to justify an award of punitive damages.

${ }^{20}$ Id.
} 
The most famous tort case by a $3^{\text {rd }}$ party against an accountant was the Ultramares ${ }^{21}$ case in New York. This case occurred shortly after the Stock Market Crash of 1929 and, perhaps because of the financial carnage the highest court in New York saw happening on Wall Street, it decided to protect the accounting profession by ruling that duties of care regarding mere negligence are only owed to those who are in privity of contract. In other words, $3^{\text {rd }}$ party users of a faulty audit report had no standing to sue the negligent accountant who produced it.

This rule was followed throughout the country until the late 1960s when a Federal District Court ${ }^{22}$ in Rhode Island questioned the continuing validity of the Ultramares holding. From that point on, various states started expanding the notion of duty of care in the negligence context regarding $3^{\text {rd }}$ party users of audit reports thus expanding the legal risks for accountants.

Most states ruled that auditors owed duties of care to all "foreseen" $3^{\text {rd }}$ parties. Some narrowly said that the $3^{\text {rd }}$ party had to be individually foreseen while others took a broader approach and said that the $3^{\text {rd }}$ party only had to be a member of a foreseen limited class of users of the audit reports. Both of these approaches were variations of the Restatement of Torts, $2^{\text {nd }} \cdot 23$

Some state courts were not satisfied with those approaches and extended the notion of duty of care in the negligence context to all "foreseeable" $3^{\text {rd }}$ parties. ${ }^{24}$ This opened up auditors to even more risk for committing professional malpractice. ${ }^{25}$

At that point people wondered if the various state courts would tend to follow the very expansive lead of these courts. Then New York - a very influential state legally - weighed in with the Credit Alliance case. ${ }^{26}$ Even though in some cases ${ }^{27}$ since Ultramares, the New York courts seemed to be expanding the notion of ${ }^{\text {rd }}$-party-duty in the negligence context, in the Credit Alliance case New York's highest court retreated back towards Ultramares requiring something close to privity.

In the $B i l y^{28}$ case, the Supreme Court of California took a similar restrictive position effectively protecting most accountants from $3^{\text {rd }}$ party lawsuits for mere negligence ${ }^{29}$.

By legislative enactment ${ }^{30}$, Utah took a very restrictive view of duties owed to $3^{\text {rd }}$ parties making it very difficult for $3^{\text {rd }}$ parties to successfully sue for mere negligence regarding faulty audit work done by accountants.

It is also interesting to note that the New Jersey legislature ${ }^{31}$ effectively overturned the rule enunciated by its state Supreme Court in the Rosenblum v. Adler ${ }^{32}$ case which was the first court in the country to enunciate a foreseeable- $3^{\text {rd }}$-party rule regarding accountants' negligence liability. It may be that when the New Jersey legislature perceived that other states were rejecting the lead of its courts, it decided to retreat back towards the privity rule regarding auditor negligence. New Jersey's rule is now very similar to Utah's rule requiring (1) a specifically foreseen $3^{\text {rd }}$ party user and (2) specific expressions of understanding by the accountant that he or she knew the $3^{\text {rd }}$ party was going to rely upon the accountant's work, before a court could hold an accountant liable to a $3^{\text {rd }}$ party user of his negligently prepared accounting work.

${ }^{21}$ Ultramares Corp. v. Touche (174 N.E. 441 (N.Y. 1931.))

${ }^{22}$ Rusch Factors v. Levin (284 F.Supp 85 (R.I. 1968.))

${ }^{23}$ Restatement of Torts, 2nd, "Section 552: Information Negligently Supplied for the Guidance of Others." The Restatements of the Laws series are academic attempts to generalize how the various states approach various legal issues. They are not authoritative, meaning that courts do not have to apply the principles expounded there, but often are guided by them and cite them in support of their holdings.

${ }^{24}$ Rosenblum v Adler (461 A.2d 138 (N.J. 1983)); Citizens State Bank v. Timm Schmitt (335 N.W.2d 361 (WI, 1983.))

${ }^{25}$ Usually the term "professional malpractice" refers to the tort of negligence, but it could broadly be used to describe all of the legal risks discussed in this article.

${ }^{26}$ Credit Alliance v. Arthur Andersen (483 N.E.2d 110 (N.Y. 1985.))

${ }^{27}$ State Street Trust v. Ernst (15 N.E. 441 (N.Y., 1938)); White v. Guarente (372 N.E.2d 315 (N.Y., 1977.))

${ }^{28}$ Bily v. Arthur Young (834 P.2d 745 (Cal. Supreme Ct. 1992.))

${ }^{29}$ Actually in Bily, the California Supreme Court said that the tort of negligence is not the right tort claim to raise in California against an accountant but rather, "negligent misrepresentation."

${ }^{30}$ Utah Code Section 58-26a-602.

${ }^{31}$ NJ Revised Stat. Section 2A:53A-25 (2014).

${ }^{32}$ Rosenblum v Adler (461 A.2d 138 (N.J. 1983.)) 
So there is a very wide continuum of approaches to the notion of duties of care owed by accountants to $3^{\text {rd }}$ party users of their negligently created audit reports. It goes from something close to privity in states like New York, California, Utah (and now New Jersey) and goes all the way to the outer bounds of foreseeability in a very few states. ${ }^{33}$ Most states are in the middle of that continuum taking a "foreseen" limited class of $3^{\text {rd }}$ party users approach.

If a court rules that the auditors owed no duty of care to the $3^{\text {rd }}$ party plaintiffs who relied upon the faulty audit report, then their negligence theory of relief will be dismissed. On the other hand, if the court rules that the auditors did owe a duty of care to the $3^{\text {rd }}$ party plaintiffs, then those plaintiffs must prove that the accountants breached that duty of care.

The big issue here is whether following GAAS and GAAP conclusively determines that the accountants met their duty of care and protects them from liability claims filed against them for negligence. In most cases following GAAS and GAAP will protect the auditors from potential negligence liability, but not always. Some courts $^{34}$ have ruled that accountants may have to go further than the dictates of the profession in order to meet their legal duty of care and fairly present the financial condition of their audit clients.

So in a negligence lawsuit against an accountant for negligent audit work, the first line of defense for the auditor is to argue that no duty of care was owed to the $3^{\text {rd }}$ party plaintiff who used the faulty audit report.

If that doesn't work, then he will argue that he met his applicable duty of care owed to that $3^{\text {rd }}$ party.

If that doesn't work, then the accountant can argue that his fault was not the "proximate cause" of the plaintiff's damages. "Proximate cause" is really a public policy determination by a court to limit how far out liability can extend.

To understand this notion, imagine a string of dominoes set up to visibly demonstrate a chain reaction. When the first domino is pushed over, all of the other dominoes in the line fall in succession, so there is no question that the requirement of "actual causation" was met (sometimes this is called the "but for test" i.e., but for pushing over the first domino, none of the other dominoes would have fallen). But even so, a court will not extend liability unless that "actual cause" was also the "proximate cause" of the plaintiff's injuries.

If we imagined each domino as representing some sort of harm caused to somebody else, the legal question becomes how far down that string of dominoes should liability be allowed to extend. At some point the extension of liability is so farfetched it becomes absurd. So when a court considers "proximate cause" issues, it is deciding where to draw a line across that string of dominoes with liability attaching to all the beginning dominoes up to that line and disallowing negligence liability claims for all the dominoes on the other side of that line. The Timm Schmidt ${ }^{35}$ case from Wisconsin explains the types of things courts may consider in determining where to draw that line under proximate cause analysis.

In addition to the foregoing, the accountant may also have some sort of affirmative defense that may lessen, if not totally eliminate, liability to the $3^{\text {rd }}$ party plaintiffs. For example, perhaps the plaintiff was also negligent in making its business decision to deal with the audit client. After all, considering the audit report is only one step in a multi-faceted decision-making process. If it was negligent in other parts of the decision making process, it shouldn't

\footnotetext{
${ }^{33}$ It may be that the few states that judicially followed the New Jersey Supreme Court's lead in Rosenblum v. Adler have also legislatively followed the lead of the New Jersey legislature and moved their states back to the "foreseen $3^{\text {rd }}$ party" realm (or even further) of potential liability. We limited our research to New Jersey since it was at the forefront of the "foreseeable $3^{\text {rd }}$ party" duty-of-care rule.

${ }^{34}$ Herzfeld v. Laventhal (540 F.2d $27\left(2^{\text {nd }}\right.$ Cir. 1976)); U.S. v. Simon (425 F.2d 796 ( $2^{\text {nd }}$ Cir. 1969.))

${ }^{35}$ In Citizens State Bank v. Timm Schmitt (335 N.W.2d 361 (WI, 1983)), the court mentioned the following things to consider in deciding where to draw the "proximate cause" line on potential negligence liability regarding accountants: (1) Was the injury too remote? (2) Was the injury too wholly out of proportion to the culpability of the negligent accountant? (3) In retrospect, does it appear too highly extraordinary that negligence should have brought about the harm actually caused? (4) Would the extension of liability pose an unreasonable burden on the accounting profession? (5) Would the allowance of liability likely open up the way for fraud? and/or (6) Would allowing recovery enter a field that has no sensible or just stopping point?
} 
be able to look to the accountant to recover all of its losses. This would entail a comparative negligence analysis where fault is apportioned between both the plaintiff and the defendant. ${ }^{36}$

It may also be that the plaintiff cannot adequately shoulder its burden of proof regarding the causal connection between the defendant-accountant's negligence and the damages the plaintiff supposedly suffered.

\section{Fraud/Deceit}

In contrast to the issue of duty of care in the negligence context, courts say that a duty of care in the fraud context is owed to all "foreseeable" $3^{\text {rd }}$ party users of the audit reports. This also came out of the old Ultramares ${ }^{37}$ case. So if the auditor's level of culpability is that serious, he faces significant liability potential and even criminal charges. Most likely, exclusions in his malpractice insurance policy exclude coverage for such behavior.

Common law fraud or deceit normally requires (1) affirmative material misstatements of fact, (2) made with "scienter," (3) made with the intention to induce the victim to act or refrain from acting in reliance upon the misrepresentation, (4) justifiable/reasonable reliance on the part of the victim, and (5) damage to the victim resulting from such reliance. ${ }^{38}$ "Scienter" means either (a) knowing falsity (i.e. an outright lie) or (b) reckless disregard of the truth. ${ }^{39}$ Basically reckless disregard of the truth means making a statement while having no reasonable foundational basis upon which to believe it to be true. Since fraud/deceit is a type of intentional tort, mere negligence on the part of the auditors is not sufficient to prove a case for fraud/deceit. Merely negligent mistaken belief that something is true does not meet the "scienter" requirement since it is not so bad as to be "reckless."

Sometimes courts use the term "constructive fraud." It may be that this is used to describe the "reckless disregard of the truth" portion of the "scienter" test as opposed to a knowing lie on the part of the defendant.

The professional misconduct of accountants seldom rise to the level of fraud/deceit since they usually don't meet the "scienter" requirement-i.e. they usually don't lie about things in their audit reports and they usually have a reasonable (though mistaken) basis upon which to believe their reports to be true. But before passing off this legal risk as being only slight, consider the following things the Ultramares ${ }^{40}$ court considered to be fraud on the part of an accountant:

1. certifying something when there is no genuine belief behind it,

2. certifying correspondence to the books without testing to see if it is true,

$3 . \quad$ closing one's eyes to the obvious, or

4. giving the pretense of knowledge when there was no knowledge on the part of the accountant.

If the plaintiff can successfully prove his case for fraud/deceit, the defendant-accountant may successfully contend that there was insufficient causal connection between his fraud and the plaintiff's injuries. For example, perhaps a portion of the plaintiff's damages can be ascribed to generally accepted business risks such as: a general downturn in the economy or a specific downturn in the plaintiff's area of business, etc.

Gross Negligence, Recklessness, Wantonness, etc.

Sometimes a defendant's conduct is worse than just negligence but better than outright fraud/deceit. Courts use different terms to describe this middle-ground between negligence and outright fraud/deceit. The various terms include: "gross negligence," "recklessness," and "wantonness." ${ }^{41}$ It may be that "constructive fraud" also fits in this middle category. For the rest of this article we will just use the term "gross negligence" to describe this middle common law tort zone.

\footnotetext{
${ }^{36}$ Rosenblum v Adler (461 A.2d 138 (N.J. 1983.))

${ }^{37}$ Ultramares Corp. v. Touche (174 N.E. 441 (N.Y. 1931.))

${ }_{38}^{38}$ Prosser and Keeton on Torts, $5^{\text {th }}$ Ed., West Hornbook Series (West Publishing Co., 1984) p.728; Restatement of Torts, 2 nd, Section 525.

${ }^{39}$ Prosser, Id.

${ }^{40}$ Ultramares Corp. v. Touche (174 N.E. 441 (N.Y. 1931.))

${ }^{41}$ Prosser, Id. pp.211-14.
} 
This middle ground is the most obscure potential area of liability. States will differ as to whom an accountant owes a duty of care. Some will probably say that an accountant's duty of care in this middle area extends to all foreseeable $3^{\text {rd }}$ party users of his statements like in a case for fraud. Others will probably limit the extension of duty in this middle area to $3^{\text {rd }}$ party members of a foreseen class of potential users of his statements.

Suffice it to say that since the accountant's level of culpability here is worse than mere negligence, in all likelihood, courts will be more generous to $3^{\text {rd }}$ party plaintiffs regarding this theory and take a more expansive view of duty of care than whatever their rule happens to be in the case of mere negligence.

Like the other two tort areas discussed above, if the plaintiff can successfully prove its case for gross negligence, perhaps the defendant-accountant can effectively reduce what the plaintiff is alleging as damages by questioning the sufficiency of the causal connection between the accountant's tortious conduct and the harms the plaintiff alleges it suffered.

\section{Federal and State Statutory Violations}

\section{C1. The 1933 Securities Exchange Commission Act}

After the stock market crashed in 1929, Congress passed the Securities Act of $1933^{42}$ to regulate the initial issuance process regarding securities. However, certain types of securities (e.g. bank securities, non-profit educational or religious entities, etc. ${ }^{43}$ ) and transactions (e.g. small offerings, intrastate offerings, private placement offerings $^{44}$ ) are exempt from having to file a registration statement with the Securities Exchange Commission (SEC) before offering securities for sale.

If a registration statement is required, accountants associated with the filing could be subject to potential civil liability exposure under Section $11^{45}$ of the ' 33 Act to the extent they were responsible for any misstatements or omissions of material facts in that registration statement. A private cause of action exists to those who acquired the associated securities and who were injured by such misstatements or omissions. ${ }^{46}$ However, no such liability will accrue if, the accountant acted with due diligence ${ }^{47}$; the misstatements or omissions of facts were not material; the plaintiff knew of the misstatements or omissions of material facts before investing; or there was no causal connection to harm. ${ }^{48}$

Even if no registration statement is filed with the SEC, accountants can be held civilly liable for any material misstatements or omissions they are responsible for in the prospectuses and other communications used to sell securities through any of the instrumentalities of interstate commerce under Section 12 of the ' 33 Act. ${ }^{49}$ No Section 12 liability will accrue if the purchaser knew (or reasonably could have known) of the untruth or omission-the plaintiff has the burden of proof regarding those matters. ${ }^{50}$

Moreover, even if exempted from filing a registration statement with the SEC, an accountant can be held liable under the ' 33 Act for any fraudulent misstatements or omissions of material facts relative to sales of securities through any of the instrumentalities of interstate commerce. ${ }^{51}$

\footnotetext{
42 15 U.S.C. 77 a.

${ }^{43} 15$ U.S.C. $77 \mathrm{c}(\mathrm{a})$.

${ }^{44} 15$ U.S.C. $77 \mathrm{c}(\mathrm{b})$.

${ }^{45} 15$ U.S.C 77k (note: when section 11 of the ' 33 Act was put into the U.S. Code, it came in as a letter instead of a number-the $11^{\text {th }}$ letter of the alphabet is " $k$ ".)

${ }^{46} 15$ U.S.C. $77 \mathrm{k}(\mathrm{a})$.

${ }^{47} 15$ U.S.C. $77 \mathrm{k}(\mathrm{b})(3)$ describes this as follows: "he had, after reasonable investigation, reasonable ground to believe and did believe, at the time such part of the registration statement became effective, that the statements therein were true and that there was no omission to state a material fact required to be stated therein or necessary to make the statements therein not misleading."

${ }^{48} 15$ U.S.C. $77 \mathrm{k}(\mathrm{b})(3)$.

${ }^{49} 15$ U.S.C. 771 (note: when section 12 of the ' 33 Act was put into the U.S. Code, it came in as a letter instead of a number-the $12^{\text {th }}$ letter of the alphabet is "l".)

${ }_{50}^{50} 15$ U.S.C. $771(\mathrm{a})(2)$.

${ }^{51} 15$ U.S.C. $77 \mathrm{q}$.
} 
Under both Sections 11 and 12, the statute of limitations for bringing civil suit will run on the earlier to occur of (1) one year after the untruth or omission either was discovered or, if earlier, should have been discovered, and (2) three years after the security was first offered to the public. ${ }^{52}$

Regarding the potential for "joint and several" civil liability under the '33 Act, see discussion below regarding the Private Securities Litigation Reform Act of 1995. Willful violations of the '33 Act will expose the accountant to a $\$ 10,000$ fine and imprisonment for up to five years. ${ }^{53}$ In addition, such willful violations can cause a civil penalty of up to $\$ 500,000 .{ }^{54}$

\section{C2. The 1934 Securities Exchange Commission Act}

The Securities Exchange Act of $1934^{55}$ was passed to "insure the maintenance of fair and honest markets" regarding transactions in securities. So basically, the ' 34 Act regulates the resale markets. Under what has come to be known as "Rule 10b-5" it is unlawful for any person to use "any manipulative or deceptive device" in connection with the purchase or sale of any security using the instrumentalities of interstate commerce. ${ }^{57}$ This includes affirmatively making "any untrue statement of a material fact" or "omit[ting] to state a material fact necessary in order to make the statement made....not misleading." 58 Usually common law fraud requires affirmative misstatements of material facts, but securities fraud under Rule 10b-5, also includes omitting material facts. The U.S. Supreme Court ruled that in order for a private cause of action ${ }^{59}$ to arise under Rule $10 \mathrm{~b}-5$, the defendant accountants must have acted with "scienter" or intent to deceive, manipulate or defraud-in other words, mere negligence will not suffice. ${ }^{60}$

The '34 Act also prohibits "insider trading",61 based upon "material, non-public information." 62 In addition to potentially being liable to any contemporaneous trader for the amount of any profit gained or loss avoided ${ }^{63}$ an inside trader can suffer civil penalties of up to three times the amount of profits gained or losses avoided. ${ }^{64}$ Moreover, criminal penalties can also be assessed as described below. Sometimes auditors are privy to material non-public information and should resist the temptation to personally trade on that information lest they violate the insider trading rules.

If an accountant makes any material misstatements or omissions of material fact in any filing with the SEC that is required by the ' 34 Act, he can face liability in private causes of action under Section $18^{65}$ of the ' 34 Act. No liability would exist under this section however, if (1) the SEC filing (containing those misstatements or omissions) did not itself ${ }^{66}$ affect the prices of the security, (2) the plaintiff knew about the misstatement or omission before buying or selling the security, (3) the plaintiff did not rely upon the filing, (4) there was no causal connection

\footnotetext{
${ }^{52} 15$ U.S.C. $77 \mathrm{~m}$.

${ }^{53} 15$ U.S.C. $77 \mathrm{x}$.

${ }^{54} 15$ U.S.C. $77 \mathrm{t}(\mathrm{d}) ; 78 \mathrm{u}-2(\mathrm{a})(1)(\mathrm{A}) ;$ \& $78 \mathrm{u}-2(\mathrm{~b})$.

${ }^{55} 15$ U.S.C. 78 a

${ }^{56} 15$ U.S.C. $78 b$.

${ }^{57} 15$ U.S.C. 78 j(b) and 17 CFR 240.10b-5 (Note: Rule 10b-5 derived from Section 10 of the '34 Act (15 U.S.C. 78 ). When Section 10 was codified in the United States Code, it came in as the $10^{\text {th }}$ letter of the alphabet ("j") rather than a number.)

${ }^{58} 17$ CFR 240.10b-5. Arthur Andersen violated Rule 10b-5 when it failed to disclose that one audit client was being defrauded by another audit client of Andersen's, which fraud affected the value of the first client's stock on a national stock exchange. Fund of Funds v. Arthur Andersen (545 F. Supp. 1314 (SDNY, 1982.))

${ }^{59}$ The term "private cause of action" means that people and entities (other than just the government itself), can bring a lawsuit over the matter.

${ }^{60}$ Ernst \& Ernst v. Hochfelder (425 U.S. 185 (March 30, 1976))

${ }^{61} 15$ U.S.C. $78 \mathrm{j}$ (second full paragraph).

${ }^{62} 15$ U.S.C. $78 \mathrm{u}-1(\mathrm{a})(1)$

${ }^{63} 15$ U.S.C. $78 \mathrm{t}-1$.

${ }^{64} 15$ U.S.C. $78 \mathrm{u}-1(\mathrm{a})(2)$.

${ }^{65} 15$ U.S.C. 78(r) (Note: when section 18 of the '34 Act was put into the U.S. Code, it came in as a letter instead of a number-the $18^{\text {th }}$ letter of the alphabet is " $\mathrm{r}$ ".)

${ }^{66}$ See the U.S. Supreme Court's discussion in footnote 31 in Ernst \& Ernst v. Hochfelder (425 U.S. 185, (March 30, 1976)). It appears the market price of the security must be affected by the SEC filing itself in order for a plaintiff to have a private cause of action under Section 18 against those responsible for that filing.
} 
between the SEC filing (containing those misstatements or omissions) and the plaintiff's damages, or (5) the accountant (a) acted in good faith and (b) had no knowledge that his statement was false or misleading. ${ }^{67}$

The U.S. Supreme Court ${ }^{68}$ said the following in discussing the foregoing "good faith" defense: "something more than negligence on the part of the defendant is required for recovery" under Section 18. So an accountant can be negligent and still satisfy the requirements for the "good faith" defense available to him under Section 18 of the '34 Act.

The statute of limitations runs on Section 18 lawsuits on the earlier to occur of (1) one year after the discovery of the facts constituting a Section 18 cause of action, or (2) 3 years after that cause of action came into being. ${ }^{69}$

Accountants could also be exposed to potential liability for material misstatements or omissions in proxy solicitation materials under Rule 14a-9 which says in part:

No solicitation subject to this regulation shall be made by means of any proxy statement, form of proxy, notice of meeting, or other form of communication, written or oral, containing any statement which, at the time and in light of the circumstances under which it is made, is false or misleading with respect to any material fact, or which omits to state any material fact necessary to make the statements made therein not false or misleading ... ${ }^{70}$

Some accountants were held criminally liable for material misstatements and omissions in unaudited financial statements attached to proxy solicitation materials. The problem was they knew there were material misstatements and omissions in those proxy materials but did not insist upon their correction by management. ${ }^{71}$

Regarding the potential for "joint and several" civil liability under the '34 Act, see discussion below regarding the Private Securities Litigation Reform Act of 1995. "Aiding and abetting" liability under the '34 Act can only exist if the defendant "knowingly or recklessly provides substantial assistance to another person" in violating the Act. $^{72}$ Civil penalties for violations of the 34 Act (other than insider trading civil penalties ${ }^{73}$ ) can go up to $\$ 500,000$. $^{74}$ Criminal penalties for willful violations of the ' 34 Act can include fines of up to $\$ 5$ million and imprisonment for up to 20 years. ${ }^{75}$

\section{C3. The Private Securities Litigation Reform Act of $1995^{76}$}

The Private Securities Litigation Reform Act of 1995 amends certain provisions of the '33 Act, the '34 Act, and the Racketeer Influenced and Corrupt Organizations (RICO) Statute.

$\underline{\text { Joint-and-Several Liability }}$

In securities litigation, often times many different parties are partially at fault for the material misstatements or omissions that form the basis of the legal claim by the plaintiff(s). When multiple parties injure others and the "joint-and-several liability" rule applies, then a plaintiff can choose to collect all of his proven

${ }^{67} 15$ U.S.C. $78(\mathrm{r})(\mathrm{a})$.

${ }^{68}$ Ernst \& Ernst v. Hochfelder (425 U.S. 185, footnote 31 (March 30, 1976)).

${ }^{69} 15$ U.S.C. $78 \mathrm{r}(\mathrm{c})$.

${ }^{70} 17$ CFR 240.14a-9(a). (Note: Rule 14a-9 derives from Section 14 of the ' 34 Act which was codified by letter rather than number in the United States Code. The $14^{\text {th }}$ letter of the alphabet is " $n$ " hence Section 14 of the ' 34 Act is codified as 15 U.S.C. 78 n.)

${ }^{71}$ U.S. v Natelli (527 F.2d $311\left(2^{\text {nd }}\right.$ Cir. 1975.))

7215 U.S.C. $78 \mathrm{t}(\mathrm{e})$. Arthur Andersen was held liable for aiding and abetting a violation of the federal securities law when it failed to notify one audit client of the fraud being committed on it by another audit client of Andersen's, which fraud affected the value of the first client's stock on a national stock exchange. . Fund of Funds v. Arthur Andersen (545 F. Supp. 1314 (SDNY, 1982.))

${ }^{73} 15$ U.S.C. $78 \mathrm{u}-1(\mathrm{a})(2)$

${ }^{74} 15$ U.S.C. $78 \mathrm{u}(\mathrm{d})(3)(\mathrm{B})$.

${ }^{75} 15$ U.S.C. $78 \mathrm{ff}(\mathrm{a})$

${ }^{76}$ Pub. L. 104-67; For a good online explanation of this Act, see: http://corporate.findlaw.com/finance/the-private-securities-litigation-reform-actof-1995.html 
damages from any one of the co-defendants or can collect from all of them as a group. In other words, a plaintiff can get $100 \%$ recovery from a single co-defendant (sometimes referred to as "the deep pocket") and leave it to that defendant to try to collect from his co-defendants on the basis of relative proportional fault.

Joint and several liability regimes often make it easy for plaintiffs to strong-arm peripheral co-defendants like accountants into huge settlements to buy their way out of potentially devastating lawsuits when other moreculpable co-defendants were the ones primarily responsible for the damages caused. This is particularly important to accountants when the more culpable co-defendant (e.g. their audit client) has gone bankrupt.

The Private Securities Litigation Reform Act of 1995 changed this regime under the '34 Act but only slightly regarding lawsuits under the ' 33 Act. Now, unless the co-defendants went so far as to commit fraud, they no longer face the prospects of joint-and-several liability in securities litigation under the ' 34 Act. In other words, they will only be severally liable to the plaintiffs to the extent of their proportionate fault. ${ }^{77}$

However, this Act only slightly modified the rule regarding defendants sued under the ' 33 Act. Except in the case of suit against an "outside director," other co-defendants face the prospects of joint and several liability in '33 Act lawsuits. $^{78}$

\section{$\underline{\text { Safe Harbor Rules for Forward-Looking Statements }}$}

For the sake of giving the marketplace access to more useful forward-looking information, Congress created a safe harbor that, to some extent, protects the issuers of such statements from potential litigation when the future does not play out as expected.

Accountants might be involved in the production of such forward-looking statements that affect the value of their clients' securities thus exposing them to potential liability under the federal securities laws. Generally speaking, if forward-looking statements contain "meaningful cautionary statements identifying important factors that could cause actual results to differ materially from those in the forward-looking statement," the issuers of such statements will be protected from potential liability claims under both the ' 33 Act and the ' 34 Act. $^{79}$ Moreover, $^{2}$ even if such cautionary statements are lacking, no liability under the federal securities laws will exist regarding forward-looking statements unless the plaintiff can prove that the defendant had "actual knowledge ...that the statement was false or misleading."

However, this safe-harbor protection does not apply within the context of financial statements prepared in accordance with generally acceptable accounting principles. ${ }^{81}$ So effectively, the protection only potentially helps accountants in other types of statements with which they are associated. Also, among other types of non-covered situations, the safe harbor rules do not protect the ones making forward-looking statements regarding initial public offerings (IPOs), tender offers, partnerships, limited liabilities companies (LLCs), penny stock companies, etc. ${ }^{82}$

The foregoing statutory rules are also expressed by the accounting profession in AT Section 301 "Financial Forecasts and Projections."

Amendments to the RICO Statute

Securities fraud will not count as a potential predicate offense necessary to violate the RICO statute unless the person was criminally convicted for it. ${ }^{83}$

\footnotetext{
${ }^{77} 15$ U.S.C. $78 \mathrm{u}-4(\mathrm{f})$.

${ }^{78} 15$ U.S.C. $77 \mathrm{k}(\mathrm{f})$.

${ }^{79} 15$ U.S.C. $77 \mathrm{z}-2$ (c) \& $78 \mathrm{u}-5(\mathrm{c})$.

${ }^{80} \mathrm{Id}$.

${ }^{81} 15$ U.S.C. $77 \mathrm{z}-2(\mathrm{~b})((2)(\mathrm{A}) \& 78 \mathrm{u}-5(\mathrm{~b})(2)(\mathrm{A})$.

${ }^{82} 15$ U.S.C. $77 z-2$ (b) \& 78u-5(b).

${ }^{83} 18$ U.S.C. 1964(c)
} 


\section{Expansion of Auditor Duties Regarding Public Companies}

Regarding audits of public companies and those private companies that are large enough ${ }^{84}$ to also be covered by the ' 34 Act, the auditors must include in their audit procedures:

1. procedures designed to provide reasonable assurance of detecting illegal acts that would have a direct and material effect on the determination of financial statement amounts;

2. procedures designed to identify related-party transactions that are material to the financial statements or otherwise require disclosure therein; and

3. an evaluation of whether there is substantial doubt about the ability of the issuer to continue as a going concern during the ensuing fiscal year. ${ }^{85}$

Unless it is clearly determined to be inconsequential, if the auditor becomes aware of illegal acts that have material effects on the financial statements, it must report them to management and make sure the audit committee becomes aware of it. If the audit committee does not notify the SEC of the auditor's report on such material illegal acts within one business day after receiving it, the auditor must either resign from the audit or furnish the SEC with a copy of its report. ${ }^{86}$ The auditor is protected from potential liability for such disclosures. ${ }^{87}$

\section{No New Independent Causes of Action}

It appears the Private Securities Litigation Reform Act of 1995 does not create any new private causes of action against accountants that are independent of the other causes of action discussed in this article. Its effect on potential professional liability is generally reducing in nature, rather than expanding. It just potentially affects our analysis of the other causes of action discussed.

For example, regarding the audits of companies required to file with the SEC under the ' 34 Act, it expands the things auditors must do to meet their duty of care in both the contract and tort contexts, and to meet their professional standing duties before the PCAOB.

\section{C4. Racketeer Influenced and Corrupt Organizations (RICO) ${ }^{88}$}

Although depending upon the circumstances an accountant can violate other provisions of the RICO statute, probably the part that has the most potential application to accountants is the following:

It shall be unlawful for any person employed by or associated with any enterprise engaged in, or the activities of which affect, interstate or foreign commerce, to conduct or participate, directly or indirectly, in the conduct of such enterprise's affairs through a pattern of racketeering activity.... ${ }^{89}$

The necessary "pattern of racketeering activity" requires at least two acts of racketeering activity committed within a 10 -year period. ${ }^{90}$

Similarly, although depending upon the circumstances an accountant may participate in other types of

\footnotetext{
${ }^{84}$ Those that have (1) at least $\$ 10$ million in total assets and (2) 2,000 or more shareholders (or if less, have at least 500 shareholders who are considered to be unaccredited investors by SEC standards). 15 U.S.C. $781(\mathrm{~g})$.

${ }^{85}$ (emphasis added) 15 U.S.C. 78j-1(a). The foregoing statutory rules are also expressed by the accounting profession in AU-C Section 250 "Illegal Acts Issues in Financial Statement Audits"; AU-C Section 550 "Auditing Related Party Transactions and Disclosures" and PCAOB Auditing Standard No. 18 "Related Parties"; and AU-C Section 570 "The Auditor's Consideration of an Entity's Ability to Continue as a Going Concern."

${ }^{86} 15$ U.S.C. 78j-1(b); AU-C Section 250 "Illegal Acts Issues in Financial Statement Audits"; PCAOB Auditing Standard No. 16, "Communications with Audit Committees," paragraph 8.

${ }^{87} 15$ U.S.C. $78 \mathrm{j}-1(\mathrm{c})$.

${ }^{88} 18$ U.S.C. Chapter 96, Sections 1961-1968.

${ }^{89} 18$ U.S.C. 1962 (c).

${ }^{90} 18$ U.S.C. 1961(5).
} 
racketeering activities listed in the statute, the following would be the most likely ones that could put accountants at risk under the RICO statute: mail fraud; wire fraud; obstruction of justice; obstruction of criminal investigations; tampering with a witness, victim, or an informant; unlawful welfare fund payments; and bankruptcy fraud (Title 11). ${ }^{91}$ As discussed in section $\mathrm{C} 3$ above, securities fraud will not count as a potential predicate offense necessary to violate the RICO statute unless the person was criminally convicted for it. ${ }^{92}$

Filing knowingly-false tax returns could be types of mail fraud or wire fraud depending upon whether the U.S. Mail or the internet was used as the means of transmission to the IRS. Sending out confirmation letters that imply things that are not true could amount to mail fraud if the sender knew the implications were false. ${ }^{93}$ Destroying documents could amount to obstruction of justice or obstruction of criminal investigations. Andersen's wholesale shredding of audit documents in the Enron case comes to mind here even though its criminal conviction did not rest upon that basis but rather, upon attempts by at least one person to alter or destroy emails regarding instructions from the firm's headquarters concerning the destruction of documents.

RICO violations can involve both civil and criminal liability. Generally, criminal conduct requires some sort of knowing and willful violation of the law-negligence is normally not sufficient to result in a criminal conviction. At the heart of most of the predicate offenses listed above, is some sort of fraud which normally entails making material misstatements of fact with scienter (i.e., either knowing falsity or reckless disregard of the truth.) These should suffice to justify both civil and criminal liability.

Criminal penalties include forfeiture of property and imprisonment for up to 20 years. ${ }^{94}$ Civil damages would entail treble damages (i.e., 3 times the actual amount of damages caused the plaintiff) plus reasonable attorney's fees. ${ }^{95}$

\section{C5. Sarbanes Oxley Act of $2002^{96}$}

Sometimes this is called "Sarbanes-Oxley," "Sarbox," or just "SOX." This was passed in response to the audit failure of Enron by its auditor, Arthur Andersen. Generally it created the Public Company Accounting Oversight Board (PCAOB) ${ }^{97}$ to regulate the audits of companies required to register under the Securities Exchange Act of 1934. Effectively the PCAOB has the power ${ }^{98}$ to modify Generally Accepted Accounting Principles (GAAP) and Generally Accepted Auditing Standards (GAAS) regarding such companies. Consequently some have described the situation as effectively bifurcating GAAP and GAAS into "little GAAP \& GAAS" and "big GAAP \& GAAS" - the former applying to companies that do not fall within the coverage of the Securities Exchange Act of 1934 and the latter applying to those that do. ${ }^{99}$

Only Registered Public Accounting Firms (RPAF) can perform the audits on companies required to register under the Securities Exchange Act of $1934^{100}$. All RPAFs are subject to audit by the PCAOB ${ }^{101}$--in other words, the auditors must themselves be audited to make sure adequate Quality Control standards are being observed in the audits of public companies. If the PCAOB finds that an RPAF has not complied with it rules, the firm could lose its authorization to audit public companies and could face civil penalties of up to $\$ 15$ million for intentional or reckless violations of those rules. ${ }^{102}$

\footnotetext{
${ }^{91} 18$ U.S.C. $1961(1)$.

${ }^{9} 18$ U.S.C. $1964(\mathrm{c})$.

${ }^{93} 1^{\text {st }}$ Federal Savings and Loan v Oppenheim (629 F. Supp. (SDNY, 1986.)) In that case the court ruled that sending out confirmation letters through the U.S. Mail which implied their client was actually holding certain securities in safe keeping when in fact, the accountants knew those securities had been hypothecated by their client, amounted to mail fraud. And since more than one such confirmation letter was sent out, the requisite "pattern of racketeering" was met regarding the RICO statute.

${ }^{94} 18$ U.S.C. 1963.

${ }^{95} 18$ U.S.C. 1964.

${ }^{96}$ Public Law 107-204.

${ }^{97} 15$ U.S.C. 7211 \& 7213(a)(1)

${ }^{98} 15$ U.S.C. 7211(c)(2) \& 7213(a)(1).

${ }^{99}$ We first heard the terms in a presentation given by BYU Prof. Kevin Stocks at a Utah Accounting Educators Conference.

${ }^{100} 15$ U.S.C. 7212

${ }^{101} 15$ U.S.C. $7211(\mathrm{c})(3) \& 7214$.

${ }^{102} 15$ U.S.C. $7215(\mathrm{c})(4) \&(5)$.
} 
At the risk of both civil and criminal penalties (including imprisonment for up to ten years), SOX requires RPAFs to keep their audit work papers for 5 years ${ }^{103}$. At that point the potential criminal penalties subside, but potential civil penalties for failure to keep the audit work papers extend for another 2 years ${ }^{104}$. So effectively, SOX requires that audit work papers be kept for a full 7 years.

SOX Section $103^{105}$ requires such things as second partner reviews of audit opinions, detailed testing and analysis of the internal controls of the audit client, compliance with certain quality control standards, etc.

Under SOX, if a RPAF performs an audit of a company covered by the '34 Act, it cannot contemporaneously perform the following non-audit services to that audit client: bookkeeping financial information systems design and implementation; appraisal or valuation services, fairness opinions, or contribution-in-kind reports; actuarial services; internal audit outsourcing services; management functions or human resources; broker or dealer, investment adviser, or investment banking services; legal services and expert services unrelated to the audit; or any other services that the PCAOB determines, by regulation, is impermissible. ${ }^{106}$

No RPAF can audit a company if either the lead partner or the reviewing partner on the audit has performed audit services to that client in each of the 5 prior fiscal years of that client. ${ }^{107}$

The auditor must report to the audit committee of the audit client, (1) all critical accounting policies and practices to be used; (2) all alternative treatments of financial information within GAAP that have been discussed with management, the ramifications of each alternative, and the alternative preferred by the auditor; and (3) other material written communications between the auditor and management of the audit client. ${ }^{108}$

For the sake of avoiding potential conflicts of interest, if the Chief Executive Officer (CEO), Chief Financial Officer (CFO), controller, or chief accounting officer of the audit client used to work for a particular RPAF and worked in any capacity on the audit of that audit client within one year prior to the current audit, it disqualifies this particular RPAF from performing the current audit. ${ }^{109}$

In summation of Sarbanes Oxley, audits of public companies have become much more complex than before and if the auditors do not comply with the requirements of SOX, they face potential civil and criminal penalties.

C6. The Internal Revenue Code

Title 26 of the United States Code is commonly referred to as the "Internal Revenue Code" (IRC). Since that is understood by all tax practitioners, it is common to drop the "Title 26" reference and just refer to various sections within that title as "IRC Section...." or "Section... of the IRC." Moreover, the symbol for "section" is often used to refer to a particular IRC section, which is two connected S's on top of one another like this: "§". So, for example, the IRC section dealing with like-kind exchanges could be referred to as either " 26 U.S.C. 1031" or "IRC $\S 1031$ " with the later form being the most commonly used by tax practitioners.

When accountants do tax work for their clients, they face many potential civil and criminal penalties. Rather than discuss them specifically, we will just give general descriptions of coverage for various IRC sections allowing the reader to read each section more carefully to determine the extent of his or her potential risk exposure for civil penalties. However, we will mention some of the maximum criminal penalties involved.

\footnotetext{
${ }^{103} 18$ U.S.C. 1520.

10415 U.S.C. 7213(a)(2)(A)(i). Note: U.S.C. means the United States Code. The U.S.C. is a compilation and codification of all general and permanent United States' federal law. See http://uscode.house.gov/

${ }^{105} 15$ U.S.C. 7213(a)(2).

${ }^{106} 15$ U.S.C. $78 \mathrm{j}-1(\mathrm{~g})$.

${ }^{107} 15$ U.S.C. $78 \mathrm{j}-1(\mathrm{j})$.

${ }^{108} 15$ U.S.C. $78 \mathrm{j}-1(\mathrm{k})$.

${ }^{109} 15$ U.S.C. $78 \mathrm{j}-1(1)$.
} 


\section{Civil Penalties:}

IRC $\S 6694$ : Understatement of taxpayer's liability by a tax return preparer.

IRC $\S 6695$ (a): Failure to furnish a copy of the tax return to the taxpayer.

IRC $\S$ 6695(b): Failure to sign a return.

IRC $\S 6695(\mathrm{c})$ : Failure to furnish the identifying number of the return preparer.

IRC $\S 6695(d)$ : Failure to retain a copy of a tax return.

IRC $\S 6695(\mathrm{e})$ : Failure to file correct information returns.

IRC $\S 6695(\mathrm{f})$ : Endorsing or negotiating a check made out to the taxpayer.

IRC $\S 6695(\mathrm{~g})$ : Failure to be diligent in determining eligibility for the earned income credit.

IRC $\S 6700$ : Promoting abusive tax shelters.

IRC § 6701: Aiding and abetting the understatement of tax liability.

IRC § 6713: Unauthorized disclosure or use of taxpayer information.

\section{Criminal Penalties:}

IRC $\S 7206$ : Fraud and false statements made to the IRS (potential fine of $\$ 100,000$ and imprisonment for up to 3 years.)

IRC \& 7207: Fraudulent returns, statements, or other documents filed with the IRS (potential fine of $\$ 10,000$ and imprisonment for up to 1 year.)

IRC §7216: Knowingly or recklessly disclosing or misusing information furnished in connection with a tax return (potential fine of $\$ 1,000$ and imprisonment for up to 1 year.)

\section{C7. State "Blue Sky Securities Laws"}

When issuing and dealing in securities, practitioners must not only consider the reach of the federal securities laws (discussed above under the "33 Act" and "34 Act"), but must also consider the reach of state securities laws which are generally referred to as "Blue Sky Laws." These are too many and varied to discuss in detail here.

\section{CONCLUSION}

As one can see from the foregoing discussion, potential liability for accountants is cumulative in nature. Several different legal theories of liability may apply to the same nucleus of facts. There are three broad theories of liability, namely, (1) contractual liability, (2) tort liability, and (3) statutory liability (both federal and state.) The flowchart attempts to prompt consideration of the major areas of concern under each broad theory of liability and discuss some of the affirmative defenses that can be raised by accountants to avoid, or at least minimize, their potential liability exposure.

\section{AUTHOR INFORMATION}

Timothy B. Lewis, J.D., MAcc, Professor of Accounting, School of Business, Southern Utah University, 351 West University Blvd., Cedar City, Utah 84720. 1-435-586-5443. He holds a Juris Doctorate degree from Brigham Young University (1979), a MAcc degree from Southern Utah University (1997), and currently teaches undergraduate and graduate Business law courses (including accountants' legal liability) at SUU. His research interests are both accountants' legal liability and Constitutional law. E-mail: lewis_t@suu.edu. (Contact author)

Jeffrey N. Barnes, DBA, MAcc, CPA, Professor of Accounting, School of Business, Southern Utah University, 351 West University Blvd., Cedar City, Utah 84720. 1-435-586-5406. He holds a DBA from the University of Phoenix's School of Advanced Studies (2013), a MAcc from Brigham Young University (1984), and teaches undergraduate and graduate auditing courses. His research interests are leadership, accounting ethics, and professional development. E-mail: barnes@suu.edu. 


\section{CLASSROOM APPLICATION}

As the auditing instructor teaches about accountants' legal liability, which is usually a chapter in most auditing textbooks covering the auditing profession, this paper could be an additional required reading and reference assignment. The professor is encouraged to review the accountants' legal liability heuristic (See Appendix A below) in class and show its usefulness when assessing a textbook problem regarding a client's potential legal liability. Please see Appendix B for example discussion.

The authors reviewed several current auditing textbooks containing a chapter covering accountants' legal liability. The authors found the accountants' legal liability heuristic contained herein, can be effectively used by accounting students to analyze textbook story problems dealing with liability issues. It is hoped that the mental frame of reference developed through using this heuristic will help the students safely plan their future audit work when they enter the profession of public accounting. Moreover, practitioners may also use this paper and its decision heuristic to mitigate their potential liability exposure. 


\section{Appendix A}

\section{Accountants' Legal Liability Heuristic: \\ Overview of Flow Chart Pages}

Note: The labeling of the heuristic, "A", "B", "C", "C1", etc. corresponds to the detailed discussion above.

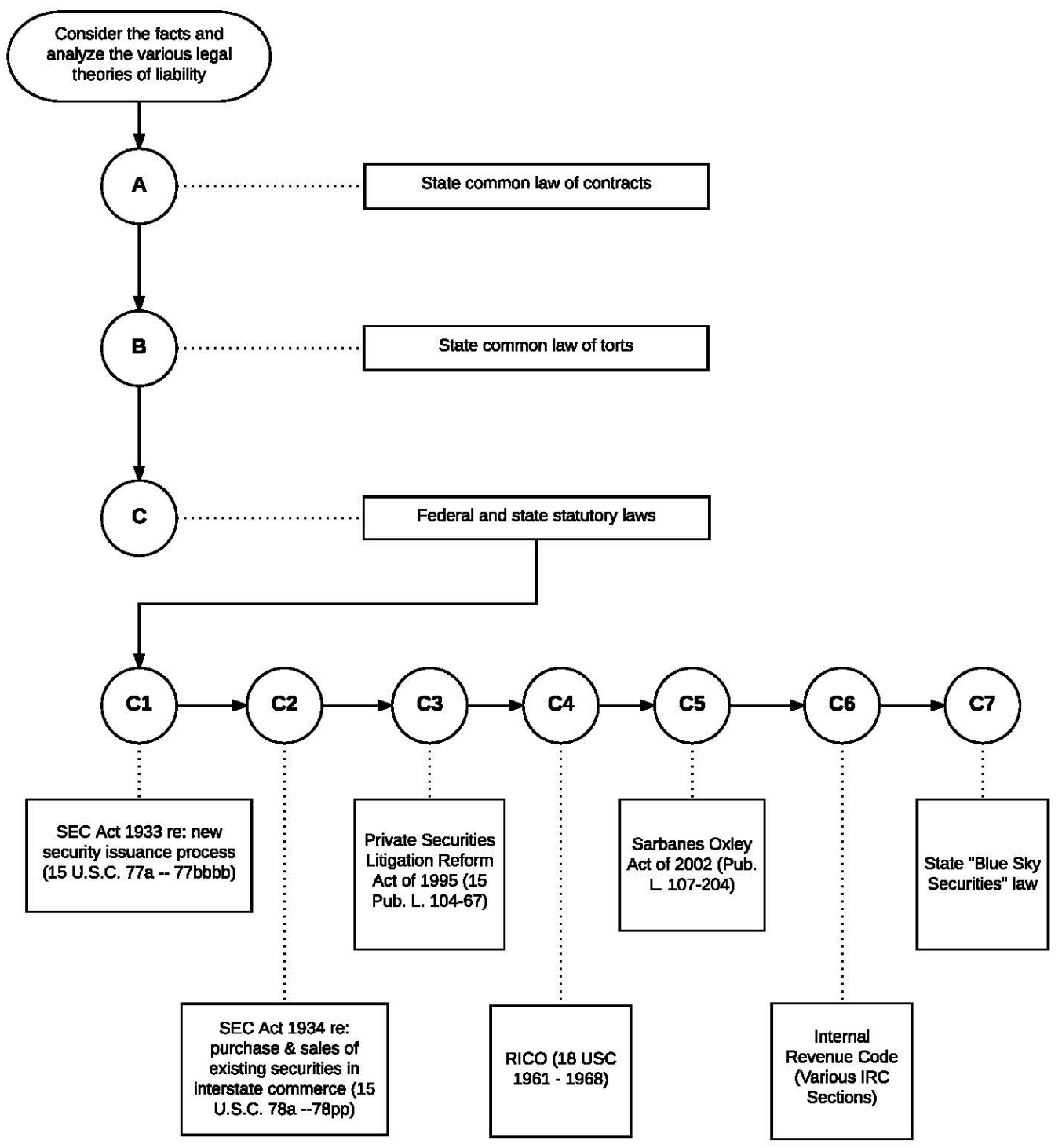




\section{Accountants' Legal Liability Heuristic: Consider the Facts and Analyze Each Potential Legal Theory of Accountant's Liability Separately and Successively} Note: There are three broad potential theories of accountants' legal liability, namely, (1) contractual liability under state law, (2) tort liability under state law, and (3) statutory liability under both federal and state law.

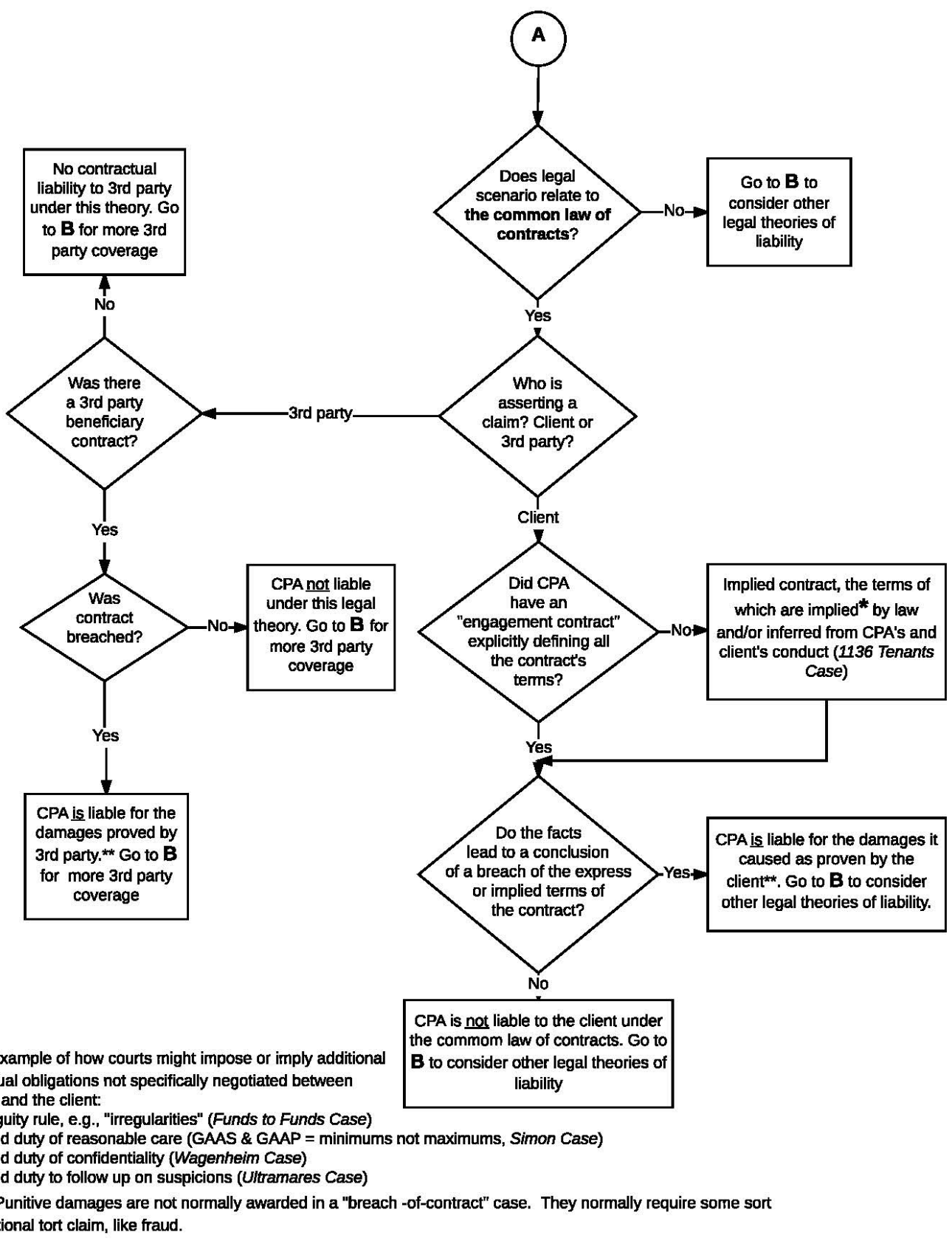




\section{Accountants' Legal Liability Heuristic: Degree of Potential Fault Under the Common Law of Torts (State law)}

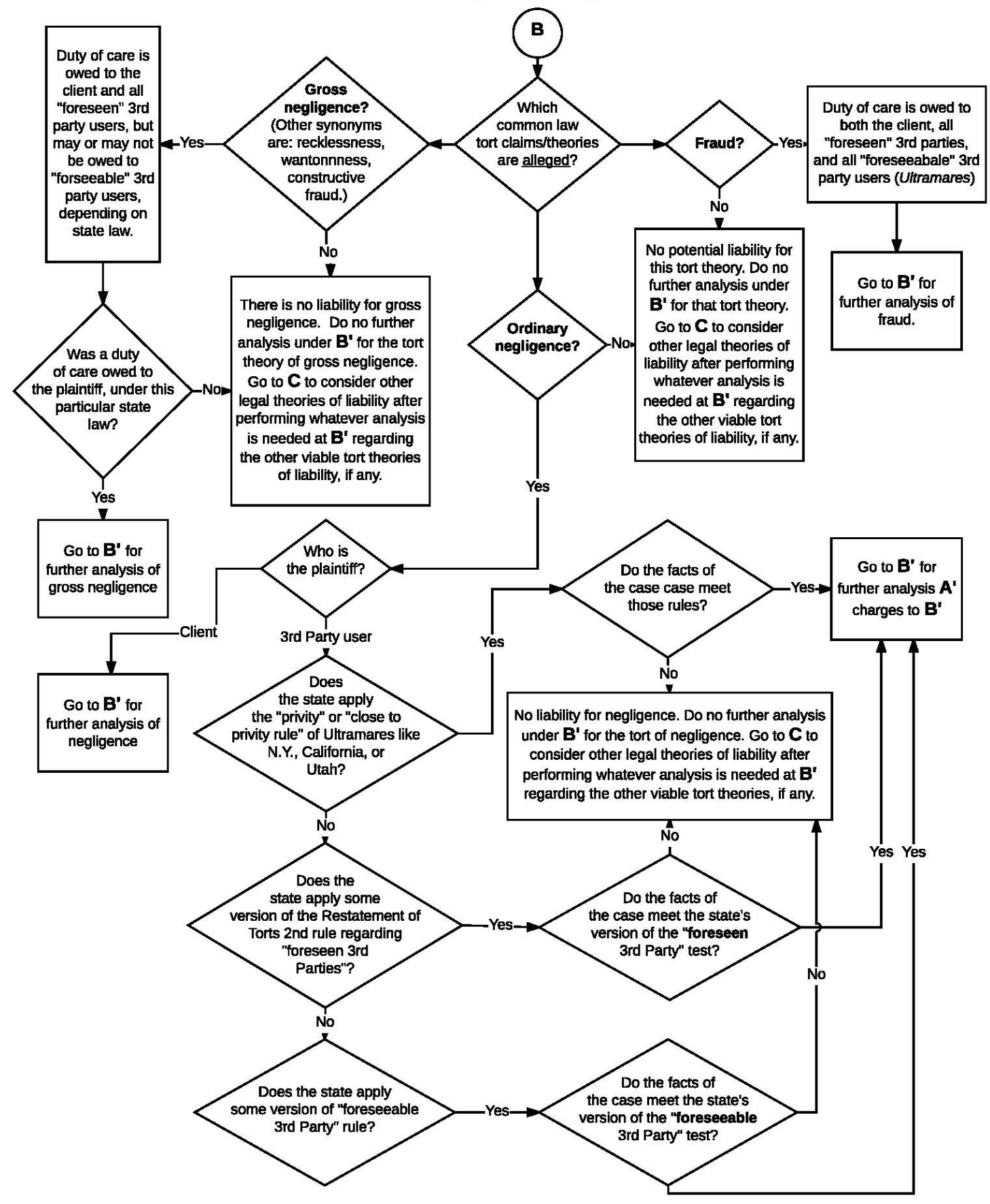




\section{Accountants' Legal Liability Heuristic: Continued Tort Liability Analysis Regarding Negligence, Gross Negligence and/or Fraud \\ Note: Separately analyze each viable theory that carried over from $\mathbf{B}$.}

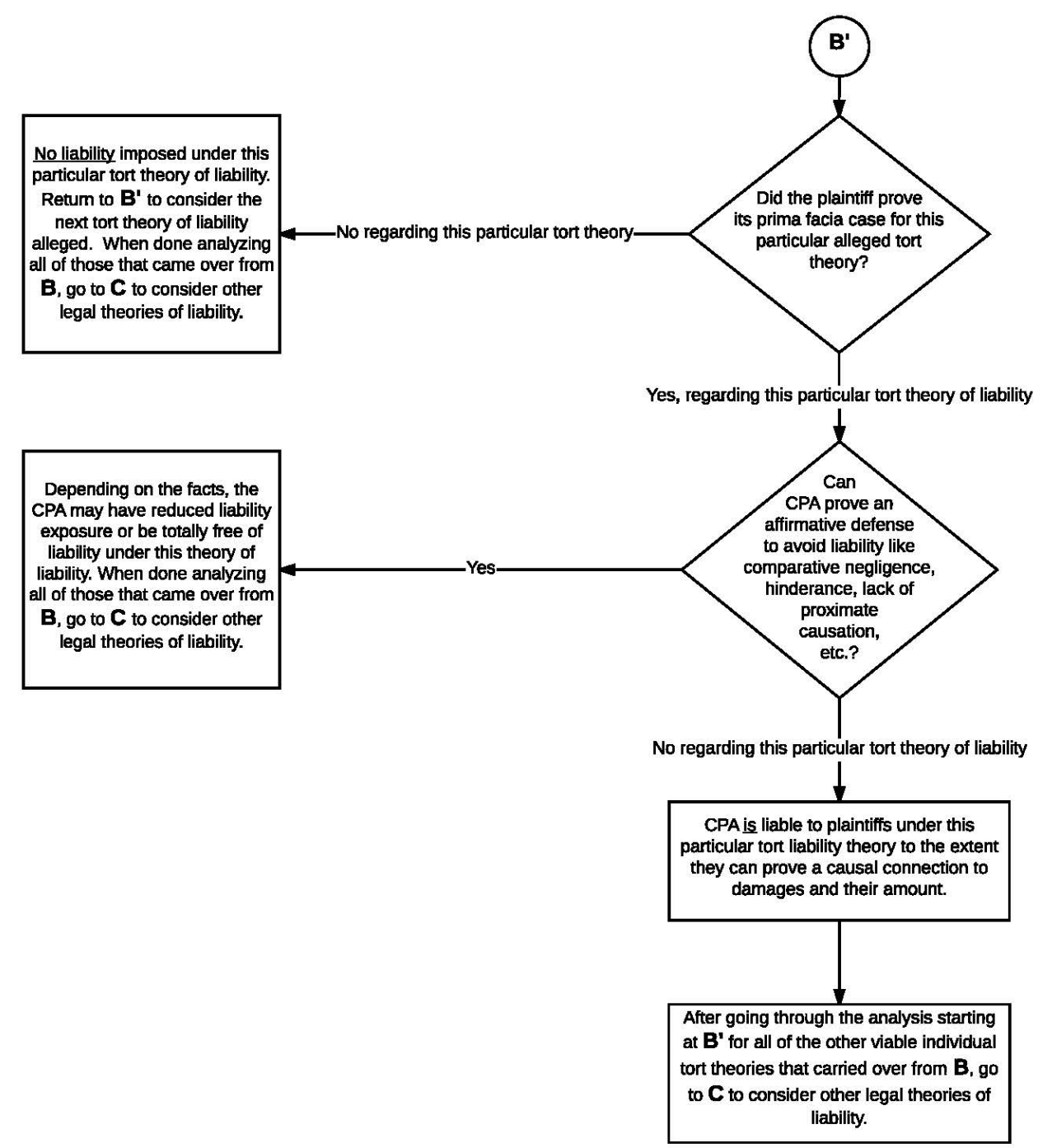


Accountants' Legal Liability Heuristic:

Federal and State Statutory Law Analysis

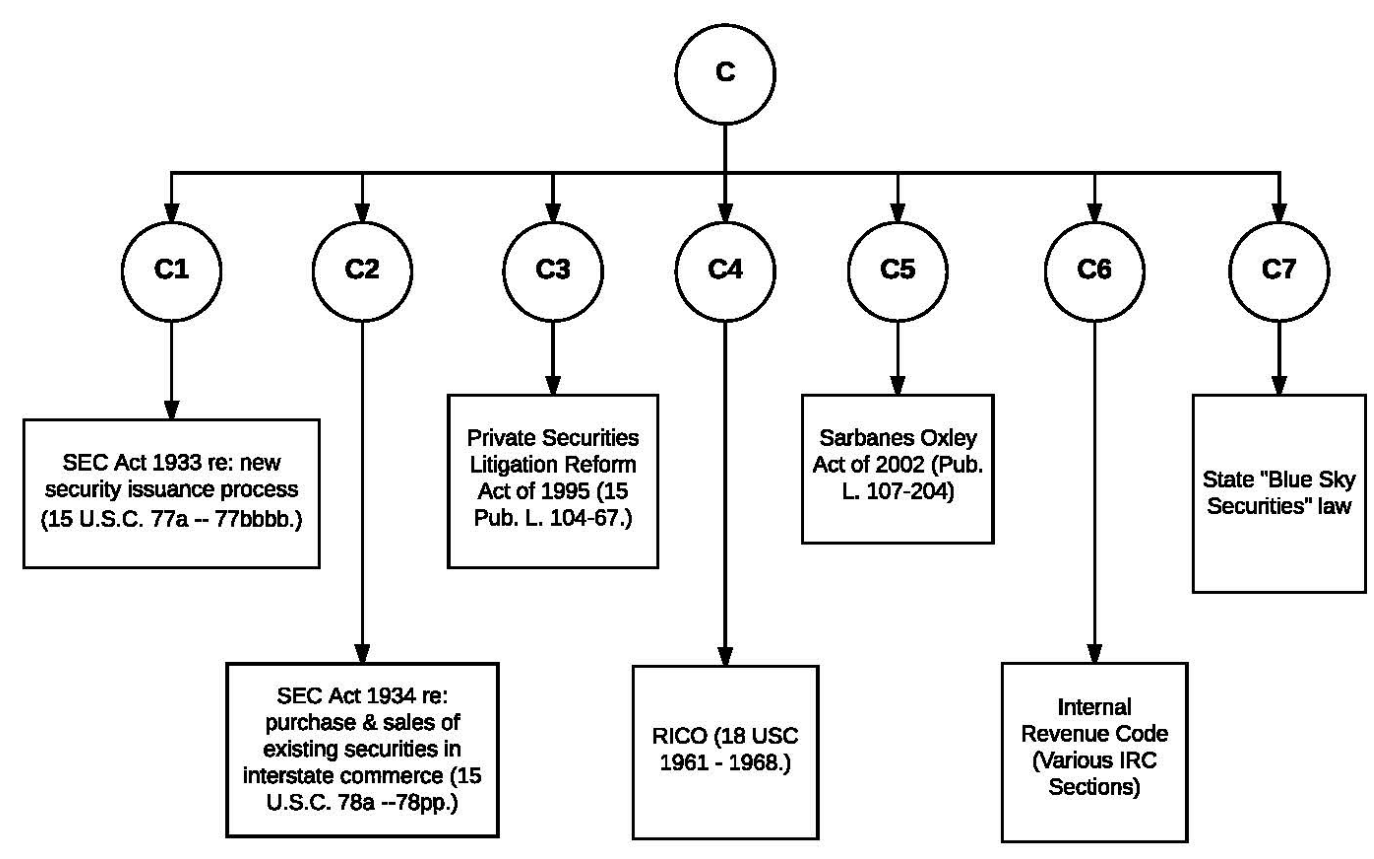


Accountants' Legal Liability Heuristic:

Federal and State Statutory Scenarios

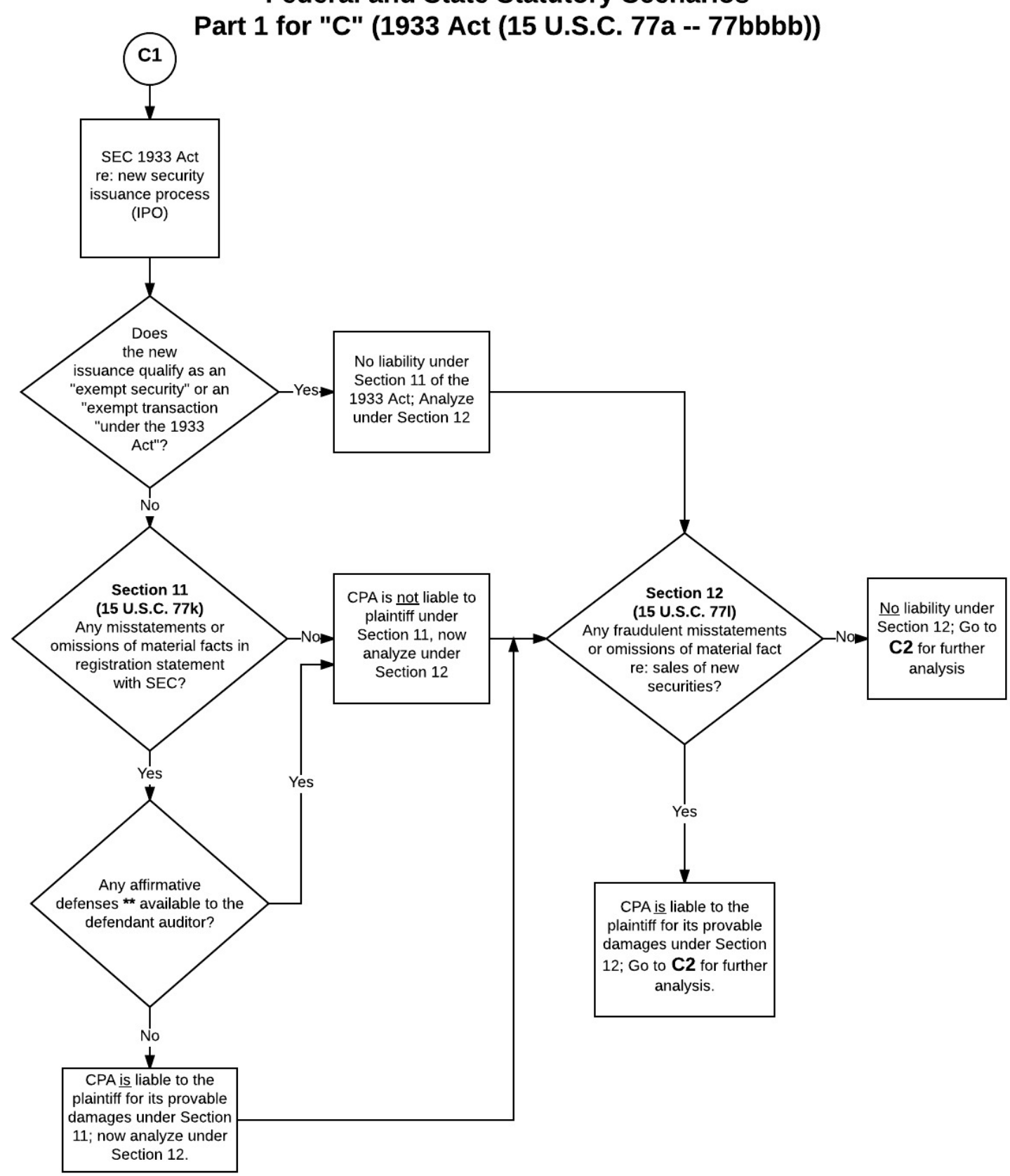

NOTE: ** CPA's potential affirmative defenses under Section 11

- the CPA acted with due diligence;

- the misstatement or omission of facts were not material:

- there was no causal connection to harm; and/or

- the plaintiff knew of misstatements or omissions of material facts before investing 


\section{Accountants' Legal Liability Heuristic: Federal and State Statutory Scenarios Part 2 for "C" (1934 Act (15 U.S.C. \$§ 78a -- 78pp))}

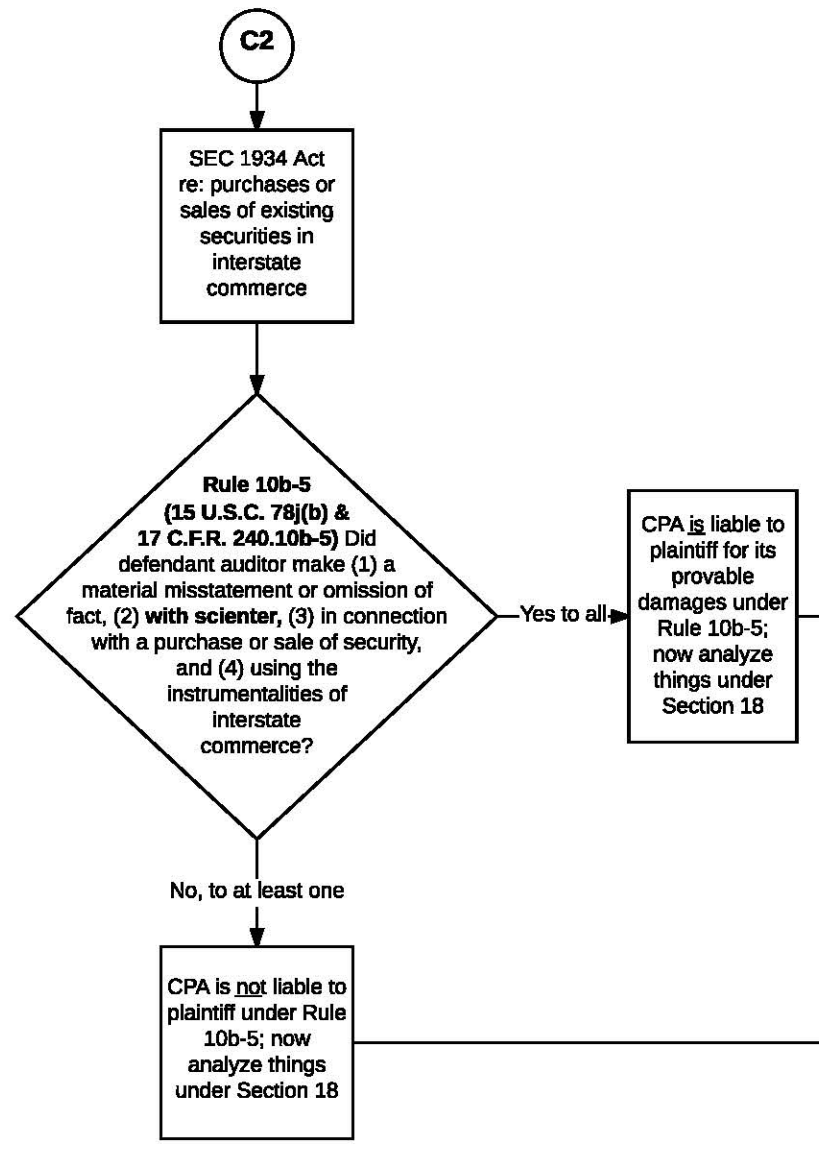

Note: See 15 U.S.C. $78 u-4 b$ regarding burdens of proof in private actions under the ' 34 Act.

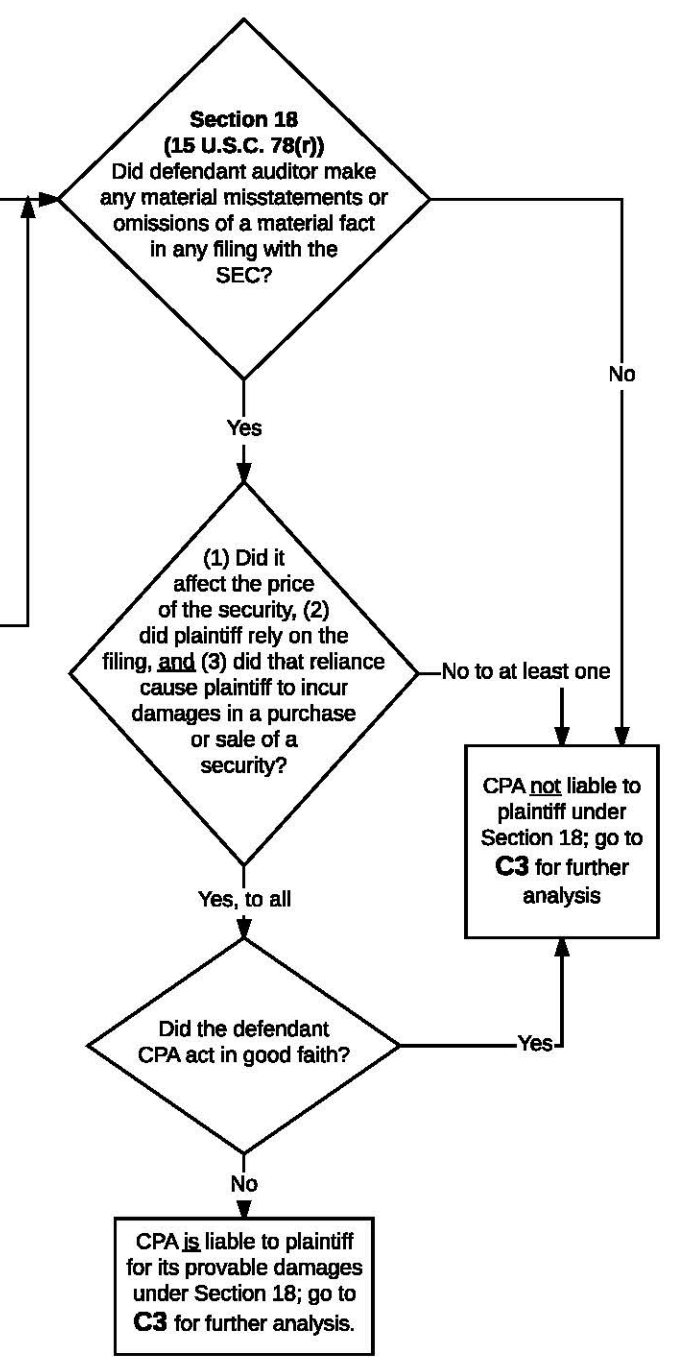




\section{Accountants' Legal Liability Heuristic: Federal and State Statutory Scenarios \\ Part 3 for "C"}

(Private Securities Litigation, Reform Act of 1995 (Pub. L. 104-67))

Note: there are two main issues to be analyzed under the Act namely, (1) forward-looking statements, and

(2) extended audit duties regarding companies covered by the ' 34 Act.

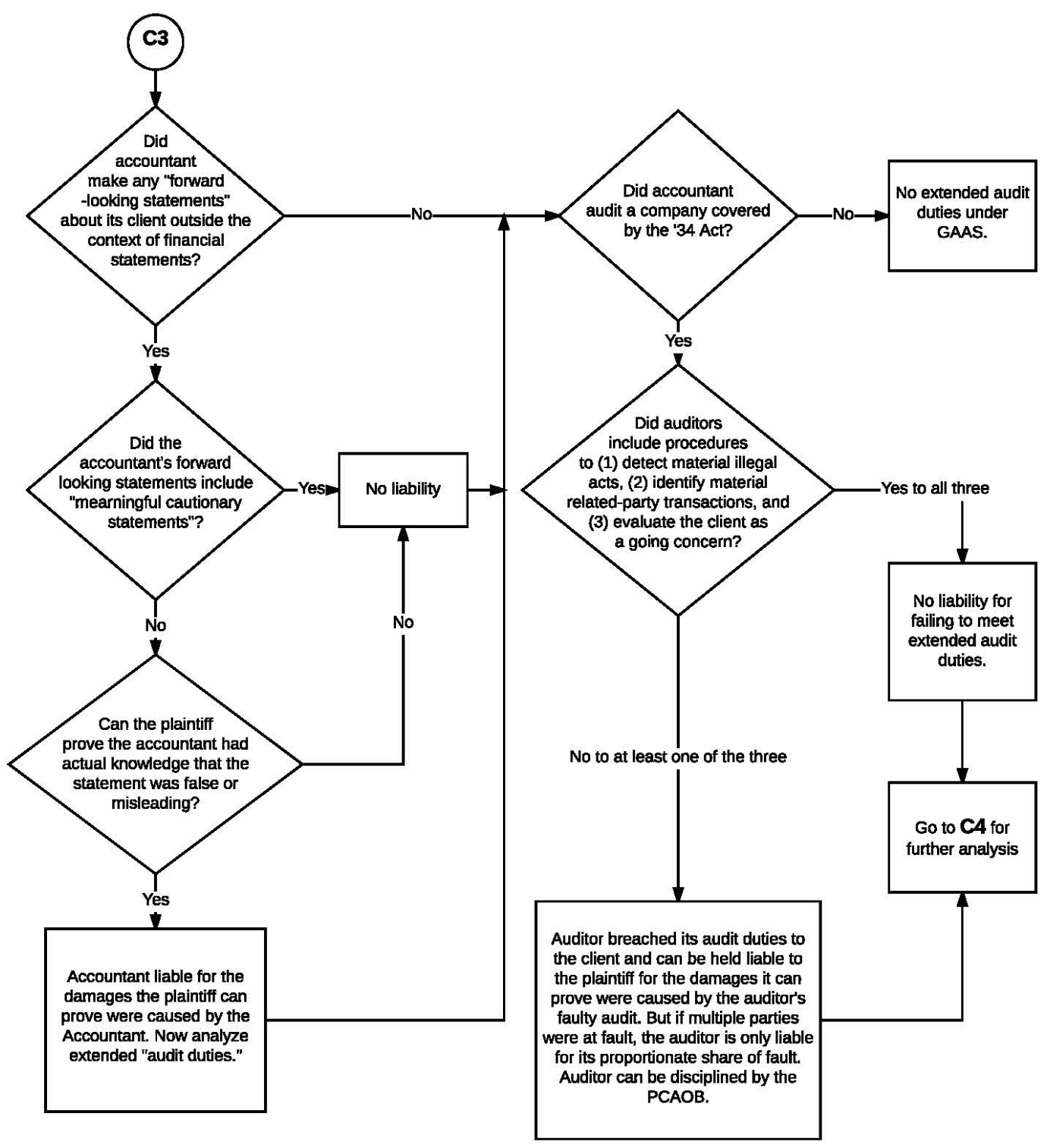




\section{Accountants' Legal Liability Heuristic:}

Federal and State Statutory Scenarios

Part 4 for "C"

(Racketeer Influence and Corrupt Organization Act (RICO)

(18 U.S.C. 1961 -- 1968))

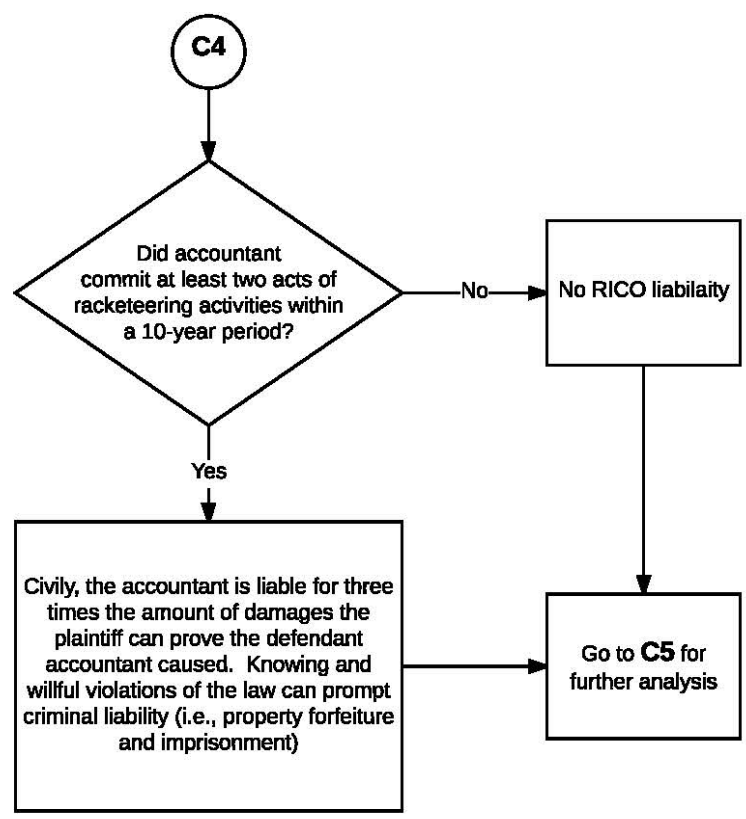




\section{Accountants' Legal Liability Heuristic: Federal and State Statutory Scenarios \\ Part 5 for "C" \\ (Sarbanes-Oxley Act of 2002, (Pub. L. 107-204))}

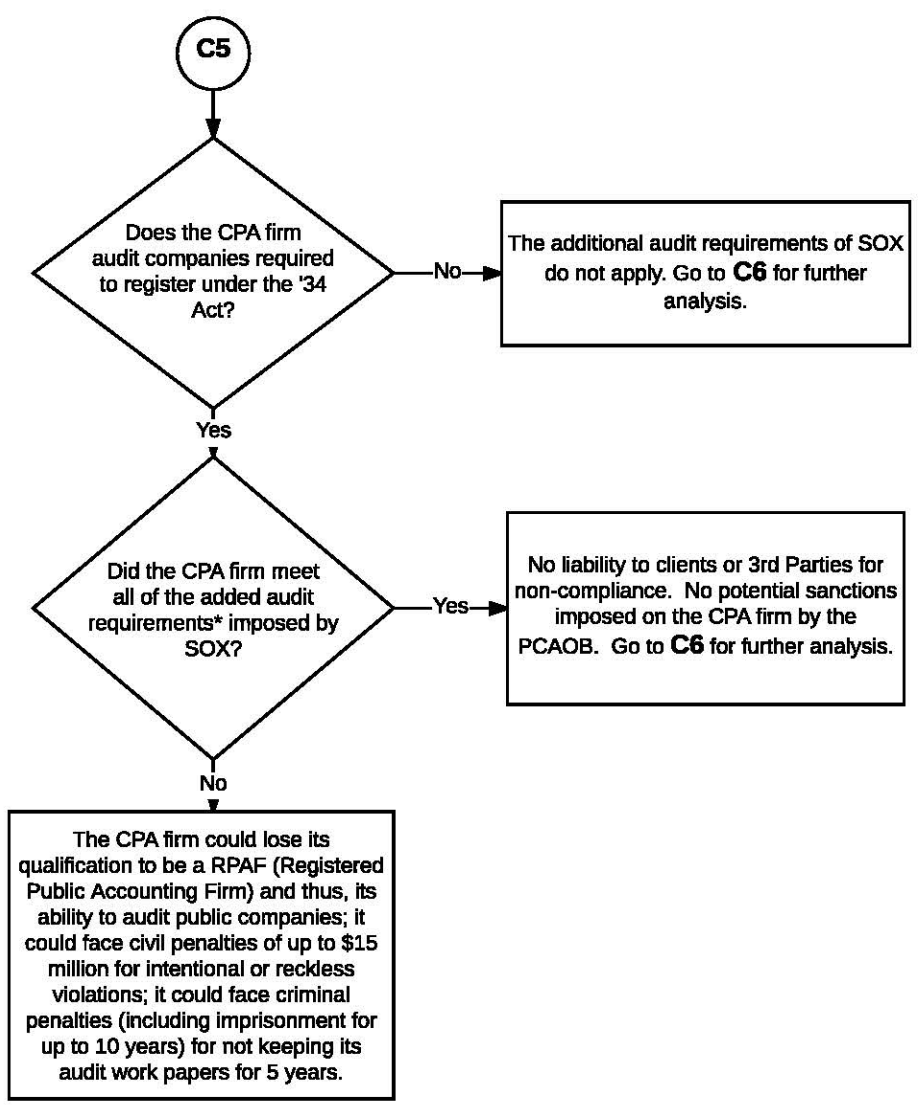

*NOTE: The CPA firm must

(1) keep its working paper for 7 years,

(2) perform second partner reviews,

(3) perform detailed testing and analysis of audit client's internal controls

(4) comply with quality control standards imposed by the PCAOB,

(5) avoid performing certain non-audit services to the client and its clients

(6) not audit any company when the lead partner or reviewing partner has performed audit services for the client for 5 straight years prior to the current

audit,

(7) not audit any company whose CEO, CFO, controller, or chief accounting officer worked for the auditor and performed audit services for the audit-client

within the last year prior to this audit, and

(8) report to the audit-client's audit committee all

(a) critical accounting policies and practices to be used

(b) altemative GAAP treatments discussed with management, the effects of its altematives, and a suggestion of the alternatives preferred to be used by

the auditors, and

(c) material written communications between the auditor and management. 


\section{Accountants' Legal Liability Heuristic: \\ Federal and State Statutory Scenarios \\ Part 6 for "C" \\ (Internal Revenue Code (U.S.C. Title 26))}

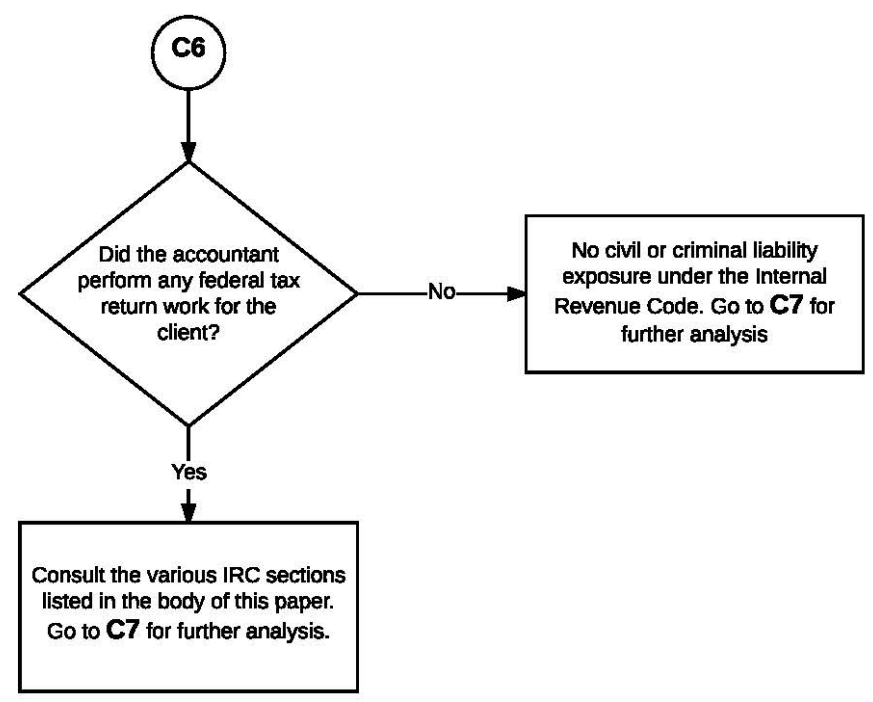




\section{Accountants' Legal Liability Heuristic: Federal and State Statutory Scenarios \\ Part 7 for "C" \\ (State Blue Sky Securities Laws)}

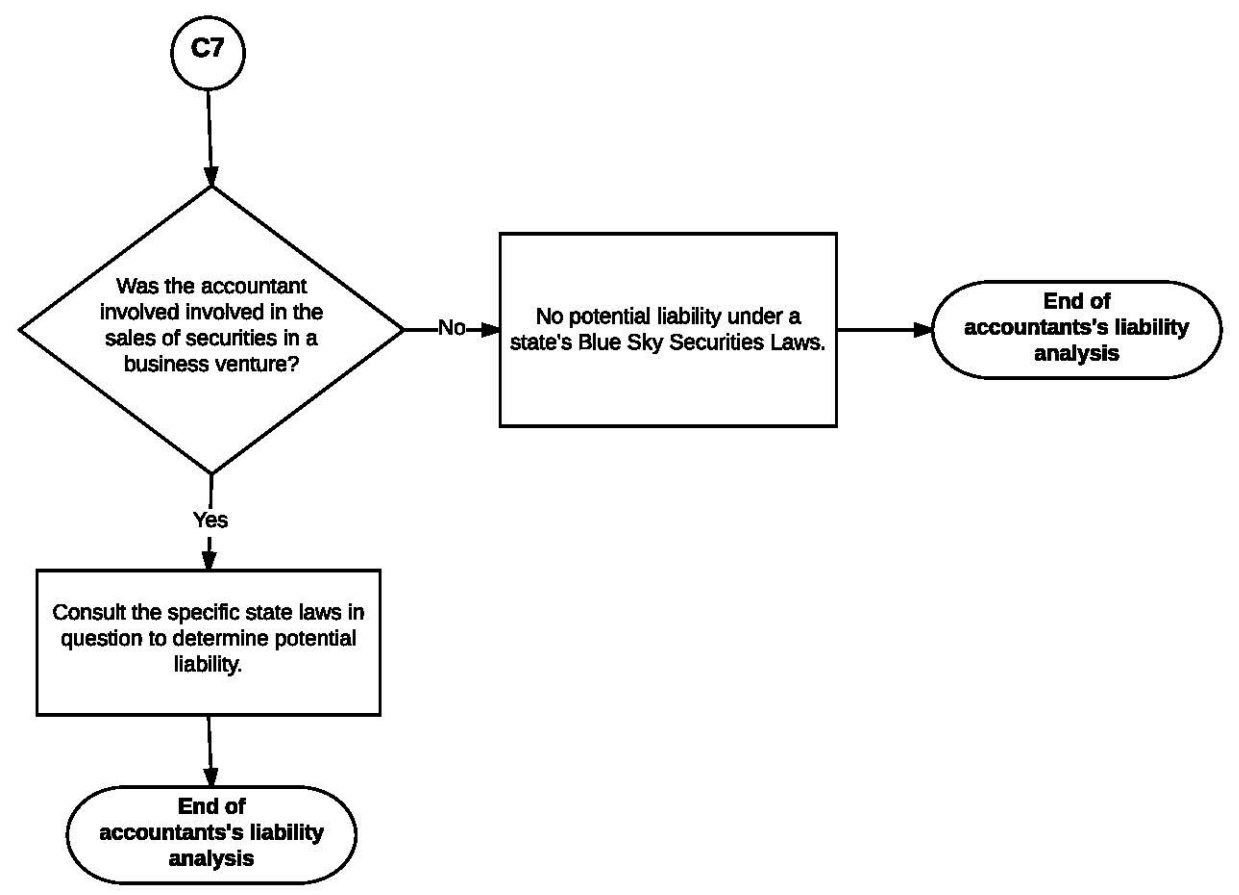




\section{Appendix B}

Discussion Example for Accountants’ Legal Liability Case

\section{The Apex Royal Flush}

Assume that after the introduction of evidence at trial (including expert accounting witnesses), a jury would conclude the following:

The Apex Company experienced unexpected sales growth, which grew by $40 \%$ this past year. The average annual growth rate in sales for the industry is only 5\%. Apex desired to expand its manufacturing capability by obtaining two sources of needed capital. First, Apex raised \$20 million in a public offering of common stock, to be used to construct a new factory. Second, Apex Company borrowed \$3 million from United Federal Bank, to purchase the new factory equipment with an additional $\$ 1$ million revolving line-of-credit to help manage cash flows.

Apex's auditors, (McDunny \& Associates, CPAs) knew that the audit report would be relied upon by United Federal Bank in making its decision to lend. Also, McDunny \& Associates helped Apex with its initial public offering (IPO) which required a registration statement to be filed with the SEC under the '33 Act. That registration statement contained the financial statements audited by McDunny.

McDunny specializes in small SEC audits. Although the McDunny auditors followed their designed audit program in performing the audit, they failed to detect $\$ 25$ million of fraudulent sales transactions which were cleverly concealed by management. The new staff auditor's sales-transaction testing was not properly reviewed. Had it been reviewed properly, additional testing probably would have been required by the partner in charge of the audit. Such additional testing probably would have revealed the fraudulent sales.

After completing the audit engagement, McDunny issued an unqualified opinion on Apex's financial statements. The financial statements and auditors' report were relied upon by investors purchasing all \$25 million of the IPO's common -stock offerings. Also, United Federal Bank relied upon them in deciding to make the $\$ 4$ million loan to Apex.

Within 90 days of the sale of stock and the extension of the loan, Apex was forced into bankruptcy by its creditors. The creditors were not paid because the corrupt management team absconded with $\$ 20$ million and fled to the Far East, never to be seen again. United Federal Bank is chartered in a state that adheres to the restrictive version of the Restatement of Torts $2^{\text {nd }}$, which requires that the $3^{\text {rd }}$ party be specifically foreseen before any legal duty of care is deemed to be owed to it regarding a negligence theory of liability. The Apex loan was made in that state.

\section{Required:}

Use the Accountants' Legal Liability Heuristic to analyze the potential liability claims against McDunny \& Associates, CPAs.

\section{Discussion:}

\section{(A) Liability under the common law of contracts:}

\section{Potential liability to the audit client:}

Unquestionably a duty of reasonable care would be an implied term of the contract between the auditor and the client even if nothing were said about it in the engagement contract.

The failure of the leaders of the audit team to review the testing of the sales transactions by the inexperienced staff accountants would probably amount to a breach of that duty of reasonable care - 
especially if the jury believes that the needed additional testing (as determined by various expert witnesses) would likely have revealed the management fraud.

A difficulty for the audit client will be in proving the amount of damages caused by the auditors' breach of contract. The primary cause of the losses to the audit client was the fraudulent conduct of its own management team - not the auditors. Arguably, if the CPAs had done adequate testing and discovered the management fraud, they probably would have issued an adverse opinion instead of an unqualified audit opinion, in which case, both the IPO and the bank loan would not have gone through. Had they not gone through, the company would never have received the $\$ 20$ million that ended up being stolen by the fraudulent management team.

But, the CPAs might effectively counter that whether or not the audit was performed properly, the company would have gone out of business anyway because of the management fraud - so how could the auditors be properly be blamed for any loss to the company (i.e. the audit client)?

\section{Potential liability to $3^{\text {rd }}$ Parties:}

Generally, under the common law of contracts, $3^{\text {rd }}$ parties have no rights or obligations under other people's contracts. The big exception is in the case of " 3 rd party beneficiary contracts."

First we must decide whether or not the $3^{\text {rd }}$ parties who are suing (i.e. the investors and the bank) are considered to be "intended beneficiaries" rather than just "incidental beneficiaries" since only the former have any viable claims under this legal theory of liability.

The bank would probably be considered to be a "creditor beneficiary" which is a type of "intended beneficiary. The investors may not have as strong a case here, but would probably also be considered to be "intended beneficiaries." After all, the CPA firm "specializes in small SEC audits" and therefore would anticipate that their audit report would be depended on by investors in making their decisions to invest in the audit client.

However, since we are told that the state in question subscribes to the restrictive version of the Restatement of Torts $2^{\text {nd }}$, regarding potential negligence liability, it may be that the state courts would be influenced by that in determining who should fit within the definition of "intended beneficiaries" under " 3 " party beneficiary contract" analysis. If they were so influenced, then probably only the bank would fit within the definition of an "intended beneficiary" thus causing the $3^{\text {rd }}$-party-beneficiary-contract theory of liability by the investors to be dismissed.

Second, "vesting" would have to occur before any $3^{\text {rd }}$ parties had any legal standing to sue under this theory. Generally, this requires the $3^{\text {rd }}$ party to (1) know about the contract between the audit client and the auditor and (2) do something to manifest his assent to the arrangement. If the state courts would consider the investors to be "intended beneficiaries," most likely, buying stock in the audit client would effectively manifest such assent. Likewise, the bank's lending of money would effectively manifest such assent.

Finally, the $3^{\text {rd }}$ parties must (1) convince the court that there was a breach of the underlying contract (which, as discussed above regarding potential contractual liability to the audit client, would probably be easy to do here under our assumed facts); (2) prove the causal connection between that breach and the injuries sustained by those $3^{\text {rd }}$ parties (this would probably be fairly simple since had the auditors done their work properly, the investors never would have invested and the bank never would have lent); and (3) prove the actual amount of damages caused by that breach. 


\section{(B) Liability under the common law of torts:}

If fruad is alleged in the compliant, our analysis at B would probably carry over to B' since, a duty of care is owed to all foreseeable $3^{\text {rd }}$ parties regarding fraud. But this theory would probably fail under our B' analysis since the culpability level of the auditors here surely would not rise to the level of fraud since the "scienter" test has not been met - the auditors did not either (1) knowingly make any material misstatements of fact or (2) make any material misstatements of fact in "reckless disregard of the truth." Failure to review a staff auditor's testing procedures seems to be an ordinary act of carelessness rather than "recklessness."

If gross negligence is alleged in the complaint, our analysis would carry over to B'only if under the state law in question, a duty of care was deemed to be owed to these particular $3^{\text {rd }}$ party plaintiffs. Since the bank would be a specifically foreseen $3^{\text {rd }}$ party user of the audit report, we would go over to B' for further analysis of this theory of liability. However, we would only carry our analysis over to B' regarding the investors, if the law of the state in question extended a duty of care under this theory of relief to all "foreseeable" $3{ }^{\text {rd }}$ party users of the audit report.

But in our analysis at B', it is doubtful the plaintiffs would win under this legal theory since failure to review a staff auditor's testing procedures seems to be just an ordinary act of carelessness rather than something more "gross" or egregious in nature. But perhaps a jury might think it was very egregious to not review a new staff auditor's testing procedures.

If mere negligence is alleged in the complaint, in our analysis at level $\mathrm{B}$, the court would probably throw out this theory of liability regarding the investors but not concerning Apex and the the bank since the bank meets the restrictive version of the extension of "duty of care" under the Restatement of Torts, $2^{\text {nd }}$. The investors weren't specifically/individually foreseen by the auditors whereas the bank was.

Under our analysis at B' regarding Apex and the bank, most likely a court would rule that the auditors breached their duty of care owed to Apex and the bank since the auditors did not follow the dictates of GAAS in failing to review the work of inexperienced staff auditors.

The auditors may be able to lessen, if not totally avoid liability under this theory, by arguing some sort of affirmative defense like comparative negligence on the part of the bank or lack of proximate causation. For example, perhaps the circumstances were such that even with the clean audit report, the bank was unreasonable in making its decision to lend money to the audit client. For instance, perhaps the audit client/borrower's industry was dying generally - maybe they were making horse buggies on the eve of the automobile revolution or typewriters on the eve of the personal computer revolution. Maybe from past business dealings they independently had reasons to doubt the integrity of the company's management team, etc.

Regarding lack of proximate causation, perhaps the court would think (in the words of the Timm Schmitt case) that the "injury was too wholly out of proportion to the culpability of the negligent accountant."

Even if the bank wins regarding those arguments by the auditors, it may still have some difficulty proving the actual amount of the damages it sustained as a result of the auditor's negligence - after all, other factors might have had some influence over what actually happened besides just what the auditors failed to do.

Regarding potential negligence liability to Apex, perhaps the auditors could lessen their potential liability by arguing the affirmative defense of comparative negligence. But depending upon the state law in question, that defense might not even be available to the auditors in trying to defend themselves in the case.

\section{(C1) Liability under the Securities Act of 1933:}

This was a new issuance of a security through the instrumentalities of interstate commerce, so the '33 Act potentially applies. If the stock issuance qualified as an exempt transaction, then no registration statement would need to be filed with the SEC and Section 11 of the '33 Act would not come into play absent a filing with the SEC. 
Apparently, the stock issuance did not qualify as an exempt transaction since a registration statement was filed with the SEC and it contained the faulty audit opinion.

Therefore, the auditors are potentially liable under Section 11 unless they could prove some affirmative defense like (1) the CPA acted with due diligence, (2) the misstatements or omissions of fact were not material, (3) there was no causal connection to harm, and/or (4) the plaintiff knew of the misstatements or omissions of material facts before investing.

Most likely, they could not convince the court that they acted with due diligence-their failure to review the testing done by inexperienced audit staff would probably not be considered to be a "reasonable investigation" providing a reasonable basis on which to believe their statement was free of misstatements or omissions of material facts. Moreover, they would probably have a hard time proving the other three affirmative defenses as well. So they will probably be liable under Section 11 for the losses incurred by the investors in buying stock in the IPO.

Even though their proportionate fault is minimal compared to the fraudulent management team who absconded with the funds, "33 Act liability among joint defendants is "joint and several" meaning that the entire judgment could be collected from the auditors.

They may also be liable to the bank under Section 11 since the word "security" is broadly defined in the '33 Act to include a "note" or "evidence of indebtedness." 110

Since Section 12 requires a finding of fraud on the part of the auditors, there is probably no Section 12 liability in play here regarding either set of plaintiffs as per our prior discussion of fraud.

\section{(C2) Liability under the Securities Exchange Act of 1934:}

There is probably no liability under the ' 34 Act either to the investors or the bank under Rule $10 \mathrm{~b}-5$ since private causes of action under it require proof of "scienter" (i.e. "intent to deceive, manipulate or defraud") and that was lacking here. Mere negligence does not amount to scienter.

Moreover, there is probably no liability to either set of plaintiffs under Section 18 since the registration statement containing the faulty audit report was required to be filed with the SEC under the ' 33 Act, not the ' 34 Act. ${ }^{11}$

But even if Section 18 potentially applied, the auditors could probably show "good faith" in what they did. While negligent conduct would probably not meet the "due diligence" defense under the ' 33 Act, it may still be able to satisfy the "good faith" defense under Section 18 of the '34 Act. Moreover, at least with respect to the bank, it probably did not rely upon the SEC filing in making its decision to lend. Rather, it probably just relied upon the audit report itself that was given to it by the borrower.

\section{(C3) Liability under the Private Securities Litigation Reform Act of 1995:}

Since the auditors did not make any "forward-looking statements," no potential liability exists concerning them and the "safe harbor" rule created by the Act becomes irrelevant.

However, this Act may have some indirect effects on the other theories of liability. Under the assumed facts, at least after the IPO and the loan from the bank occurred, the company had over $\$ 10$ million in assets. If it

\footnotetext{
${ }^{110} 15$ U.S.C. $77 b(a)(1)$.

111 U.S.C. 78r(a); 78o(d); 781; 78m. Effectively, registration statements regarding companies traded over the stock exchanges or otherwise covered by the '34 Act must be kept current with supplemental filings with the SEC. Those supplemental filings relative to registration statements fall under the ' 34 Act. But in our case, we are just talking about an initial registration statement for a company that has not heretofore been traded over any stock exchanges. So in the language of Section 18 (!5 U.S.C. 78r(a)) which provides a private cause of action under the '34 Act for misstatements or omissions in SEC filings, the initial registration statement probably does not amount to an "application, report, or document filed pursuant to this chapter" or in other words, pursuant to the '34 Act.
} 
had 2,000 or more shareholders (or at least 500 shareholders who were considered to be unaccredited investors) then the company would be covered by the ' 34 Act and become subject to periodic filing requirements with the SEC. ${ }^{112}$ Regarding such companies, auditors have increased auditing requirements - they must design their audits to detect illegal acts, related-party transactions, and assess the company's ability to continue as a "going concern." Moreover, they must comply with strict notification rules (regarding the Board of Directors of the audit client, and the SEC) if they happen to discover evidence of any illegal acts during the course of their audit.

Those additional mandates effectively expand the auditors' implied duty of care owed to the client and (potentially) owed to $3^{\text {rd }}$ parties (depending upon to whom a duty of care is owed in the tort context under state law which was discussed earlier.)

Failure to do those things would probably cause them to be deemed to have (1) breached the implied terms of their contract with the audit client and (2) committed the tort of negligence (and perhaps even gross negligence if their audit failures were gross or egregious enough.)

\section{(C4) Liability under RICO:}

Most likely there were no RICO violations under our assumed facts since it requires the commission of at least two predicate offenses within a 10 year period. All of the predicate offenses that most likely would apply to accountants require some sort of knowing fraud by the accountants, which, as discussed earlier, probably did not occur here. At worst, the auditors were only negligent in performing their audit.

\section{(C5) Liability under the Sarbanes Oxley Act of 2002:}

If the audit client is covered by the ' 34 Act (see discussion under $\mathrm{C} 3$ above) then the auditor faces additional requirements (e.g. record-keeping requirements) and prohibitions (e.g. prohibitions against auditing particular companies depending upon the many circumstances discussed in this article.) The PCAOB is authorized to modify GAAP and GAAS regarding the audits of such companies. To the extent it does so, it modifies the duty of care owed by the auditors to the audit client and (potentially) owed to $3^{\text {rd }}$ parties (depending upon to whom a duty of care is owed in the tort context under state law which was discussed earlier.)

Failure to do those things would probably cause them to be deemed to have (1) breached the implied terms of their contract with the audit client and (2) committed the tort of negligence (and perhaps even gross negligence if the audit failures were gross or egregious enough.)

\section{(C6) Liability under the Internal Revenue Code:}

The assumed facts of our case have nothing to do with taxes, so there would probably be no potential liability exposure to the auditors under the Internal Revenue Code.

\section{(C7) Liability under state Blue Sky Securities Laws:}

State Blue Sky Securities Laws are so diverse and the coverage in this article regarding them is so sparse, it is impossible to analyze things under this legal theory of liability in any detail. Suffice it to say that because the audit report affected securities sold in the IPO, the Blue Sky laws of the state where the sales took place must be researched and analyzed to determine potential auditor liability under them.

${ }^{112} 15$ U.S.C. $781(\mathrm{~g})$. 


\section{Summary of the foregoing analysis:}

Most likely, the auditors will be liable (to some extent) to the following parties under the following legal theories of liability:

Apex: Breach of contract

The tort of negligence

United Federal Bank:

Breach of contract under $3^{\text {rd }}$ party beneficiary contract rules but only if the court deems the bank to be an "intended beneficiary" under those rules

The tort of negligence

Section 11 under the ' 33 Act

The people who bought securities in the IPO:

Section 11 under the ' 33 Act

State Blue Sky Securities Laws 


\section{NOTES}

